PRZEGLĄD NAUK HISTORYCZNYCH 2016, R. XV, NR 1

http://dx.doi.org/10.18778/1644-857X.15.01.03

ZBigniew ANusiK

(UNIWERSYTET ŁÓDZKI)*

\title{
Wydarzenia we Francji w pierwszych miesiącach rewolucji (maj-październik 1789 roku) w świetle doniesień ambasadora Szwecji w Paryżu (Wersalu) Erika Magnusa Staëla von Holsteina
}

Streszczenie. Erik Magnus Staël von Holstein (1749-1802) był szwedzkim żołnierzem i dyplomatą. W listopadzie 1783 r. został mianowany ambasadorem na dworze francuskim. W styczniu 1786 r. poślubił Annę Louisę Germaine Necker, córkę szwajcarskiego bankiera i jednego $z$ najbogatszych ludzi we Francji - Jacquesa. Po ślubie $z$ córką wpływowego polityka, jakim był Necker, pozycja ambasadora Szwecji we Francji była zupełnie wyjatkowa. Był on bowiem bardzo dobrze widziany zarówno w Wersalu, gdzie cieszył się sympatią Ludwika XVI, Marii Antoniny, książąt krwi, szlachty i dworzan, jak i w Paryżu, gdzie przez swojego teścia nawiązał kontakty ze środowiskiem finansistów, kupców i szlachty urzędniczej. Staël von Holstein był także znakomitym obserwatorem francuskiej sceny politycznej. Jego poglądy polityczne skłaniały go do popierania koncepcji monarchii konstytucyjnej. $Z$ tego powodu potępiał despotyzm zarówno Ludwika XVI, jak i swojego króla - Gustawa III. Przez współczesnych był uważany za arystokratycznego liberała. Po objęciu funkcji oficjalnego reprezentanta interesów króla Szwecji na dworze wersalskim Erik Magnus Staël von Holstein przesyłał do Sztokholmu bardzo interesujace raporty dyplomatyczne, w których odnotowywał wszystkie ważniejsze wydarzenia polityczne zachodzące we Francji. W okresie, kiedy absolutna monarchia Ludwika XVI zaczęła się chwiać w posadach, jako arystokratyczny liberał i zięć Neckera sympatyzował $z$ opozycja szlachty i parlamentów skierowaną przeciwko poczynaniom rządu królewskiego. Na podstawie bardzo szczegółowych raportów szwedzkiego dyplomaty można też prześledzić przebieg tzw. rewolty uprzywilejowanych $z$ lat $1787-1788$. W pierwszych miesiaccach rewolucji Staël von Holstein przesyłał do Sztokholmu pełne głębi i politycznej przenikliwości raporty dyplomatyczne ze szczegółowym opisem wypadków zachodzacych we Francji. Przedstawiany przez Staëla obraz francuskiej sceny politycznej nie różni

\footnotetext{
* Wydział Filozoficzno-Historyczny, Instytut Historii, Katedra Historii Nowożytnej.
} 
się w zasadzie od tego, co można znaleźć w pracach współczesnych badaczy dziejów rewolucji francuskiej. Relacjom Staëla von Holsteina nie sposób też zarzucić jakiejkolwiek nierzetelności. Ambasador był bowiem na ogół znakomicie poinformowany o wszystkim, co rozgrywało się wówczas we Francji, a jeśli nawet czasami mylił się w jakichś drobnych szczegółach, to i tak najważniejszy wydaje się fakt, że był w stanie przeniknąc istotę i atmosferę przemian dokonujących się w kraju, który zwykł był uważać za swoją drugą ojczyznę.

Słowa kluczowe: Szwecja-Francja w XVIII wieku, szwedzka służba dyplomatyczna, rewolucja francuska 1789-1799, Erik Magnus Staël von Holstein.

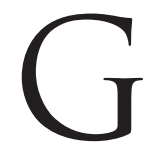

łówny bohater niniejszego studium, Erik Magnus Staël von Holstein urodził się 25 października 1749 r. w Loddby w Östergotlandii jako syn porucznika armii szwedzkiej Mattiasa Gustafa (1701-1757) i Elisabeth Ulfsparre af Broxvik (1717-1773). Wcześnie osierocony przez ojca, w wieku 11 lat wstapił jako ochotnik do regimentu piechoty Östgota. Awansowany do stopnia sierżanta (w 1763 r.), a następnie chorażego (w 1768 r.), w 1772 r. dosłużył się stopnia porucznika. W marcu 1773 r. przeszedł do służby w regimencie Södermanlands, w którym zakończył czynna służbę wojskową. Mianowany w 1776 r. szambelanem królowej Zofii Magdaleny, nie zamierzał jednak pozostać dłużej na dworze. Był bowiem bardzo ambitny i marzył o innym przebiegu dalszej kariery. Jego pragnienia spełniły się w 1778 r., kiedy został przydzielony do personelu ambasady szwedzkiej w Paryżu. Od poczatku swojego pobytu we Francji przystojny, inteligentny i dowcipny młodzieniec brylował wśród pięknych pań w Wersalu. Bardzo szybko zainteresował się też jedna z najposażniejszych francuskich jedynaczek. Już 26 czerwca 1779 r. zwrócił się bowiem z prośba do Gustawa III, proszac go o protekcję w sprawie podjętych przez siebie starań o rękę panny Necker. Ponieważ jednak jego wybranka miała wówczas zaledwie 13 lat, plany matrymonialne musiał odłożyć na później. W marcu 1780 r. młody dyplomata został awansowany do rangi sztabskapitana w swoim macierzystym regimencie Södermanlands, co wiązało się z podwyżka jego dotychczasowego uposażenia. W miarę przedłużającego się pobytu we Francji Staël von Holstein coraz bardziej zbliżał się do ambasadora Gustava Philipa Creutza. Ten ostatni stał się też dość szybko jego oddanym przyjacielem i gorliwym protektorem. W kwietniu $1782 \mathrm{r}$. Creutz rozpoczął zabiegi o to, by po jego spodziewanym wyjeździe z Paryża Erik Magnus Staël von Holstein otrzymał nominację na stanowisko 
reprezentanta interesów szwedzkich w stolicy Francji. Creutz, który w tym samym czasie usilnie naciskał na Jacquesa Neckera, aby wyraził zgodę na małżeństwo córki, pisał do Gustawa III, że jeśli zapewni Staëlowi następstwo na ambasadzie paryskiej, to wejdzie on $\mathrm{w}$ posiadanie jednej $z$ największych fortun europejskich. Według jego oceny majątek Neckera był bowiem równy pod względem wartości majątkowi jednego $z$ najbogatszych panów francuskich - Charlesa de Rohan księcia de Soubise. W tym samym czasie Staël postarał się również o protekcję stałej i najważniejszej korespondentki króla szwedzkiego - hrabiny de Boufflers. Jego kandydatura na stanowisko następcy Creutza została także poparta przez Ludwika XVI i Marię Antoninę. W tej sytuacji Gustaw III, który początkowo był przeciwny tej nominacji, wyraził wreszcie swoją zgodę. Wiosna 1783 r. Gustav Philip Creutz został wezwany do kraju, aby objać kierownictwo resortu spraw zagranicznych. Wraz ze stosownymi rozkazami dla Creutza przysłano ze Sztokholmu nominację dla Staëla von Holsteina na stanowisko chargé d'affaires Szwecji przy dworze wersalskim. Dnia 31 lipca 1783 r. Staël został awansowany do godności ministra pełnomocnego, by w listopadzie tego roku otrzymać od króla nominację na stanowisko ambasadora Szwecji w Paryżu. Przy tej okazji Gustaw III pisał z Florencji do nowo kreowanego ambasadora: „Jeśli poślubi pan pannę Necker, zostanie pan najbogatszym szlachcicem w naszej ojczyźnie i będzie pan mógł powiedzieć to samo, co Cezar, który wolał być pierwszym u siebie niż drugim w Rzymie".

Droga do ręki i majątku Anne Louise Germaine Necker nie była jednak łatwa. Przyszły teść stawiał bowiem wygórowane warunki. W dniu 21 maja 1784 r. Staël przedstawił je królowi. Były minister finansów Ludwika XVI zażądał: 1. Zapewnienia Staëlowi ambasady paryskiej „na zawsze”; 2. Dożywotniej pensji dla przyszłego zięcia w wysokości 25 tys. liwrów rocznie, gdyby kiedyś stracił stanowisko ambasadora; 3. Nadania mu przez króla Szwecji tytułu hrabiowskiego; 4. Odznaczenia go orderem Gwiazdy Polarnej; 5. Złożenia przez Staëla deklaracji, że nigdy nie zmusi swojej żony do zamieszkania w Szwecji; 6. Złożenia przez Marię Antoninę oświadczenia, że ona sama życzy sobie tego małżeństwa. Od tej pory wszystko miało zależeć od przyjęcia tych żądań przez Gustawa III. Osobista wizyta króla Szwecji w Paryżu w czerwcu i lipcu 1784 r. doprowadziła wreszcie do zamknięcia ciagnących się od kilku lat negocjacji w sprawie małżeństwa Erika Magnusa Staëla von Holsteina. 
Gustaw III zaakceptował bowiem większość przedstawionych mu przez Neckera postulatów. Na ceremonię zaślubin młodej pary przyszło jednak jeszcze trochę poczekać. Dopiero w sobotę, 14 stycznia 1786 r., w kaplicy ambasady szwedzkiej w Paryżu odbył się bowiem długo odkładany ślub Staëla i niespełna dwudziestoletniej panny Necker. Dzięki nowej ambasadorowej salon legacji szwedzkiej już wkrótce stał się jednym $z$ najświetniejszych salonów w stolicy Francji. Erik Magnus Staël von Holstein znalazł też w osobie młodej żony oddana współpracowniczkę. W latach 1786-1791 opracowywała ona, przeznaczone dla Gustawa III Bulletins de nouvelles, w których informowała króla o najnowszych trendach w zakresie francuskiej mody i literatury. Po ślubie $z$ córką Jacquesa Neckera pozycja ambasadora szwedzkiego we Francji była zupełnie wyjątkowa. Był on bowiem dobrze widziany zarówno w Wersalu, gdzie cieszył się sympatia ze strony Ludwika XVI, Marii Antoniny, książąt krwi, arystokracji i dworzan, jak i w Paryżu, gdzie przez teścia nawiązał kontakty $z$ finansjera, kupcami i środowiskiem szlachty urzędniczej. Staël okazał się także znakomitym obserwatorem francuskiej sceny politycznej. Pod względem przekonań politycznych był zwolennikiem monarchii konstytucyjnej. $Z$ tego względu potępiał despotyzm tak Ludwika XVI, jak i swojego monarchy. Powszechnie uważano go za arystokratycznego liberała, aczkolwiek arystokratyczny tytuł barona otrzymać miał dopiero, w rezultacie usilnych zabiegów swojego teścia na dworze sztokholmskim, w dniu 24 stycznia 1788 r. $^{1}$

${ }^{1}$ Por. A. G effroy, Gustave III et la cour de France. Suivi d'une étude critique sur Marie-Antoinette et Louis XVI apocryphes, t. I, Paris 1867, s. 365-375, 378 -385; L. Le ouz on Le Duc, Introduction, [w:] Correspondance diplomatique de baron de Staël-Holstein ambassadeur de Suède en France et de son successeur comme chargé d'affaires le baron Brinkman. Documents inédits sur la révolution (1783-1799) recouillis aux Archives Royales se Suède [dalej: Corr. Staël-Holstein], publ. L. Leouzon Le Duc, Paris 1881, s. IV-XVII; K. Kum1jen, Staël von Holstein Erik Magnus, [w:] Svenska Män och Kvinnor. Biografisk Uppslagsbok, Bd VII, Stockholm 1954, s. 172; Den introducerade svenska adelns ättartavlor, utg. G. Elgenstierna, Bd VII, Stockholm 1932, s. 519-520; H.A. Barton, Gustav III of Sweden and the Enlightement, „Eighteenth Century Studies. An Interdisciplinary Journal”, vol. VI, No. 1, Berkeley (University of California) 1972-1973, s. 23; Repertorium der diplomatischen Vertreter aller Länder, Bd III (1764-1815), hrsg. O.F. Winter, Graz-Köln 1965, s. 408. Por. też J. Wickman, Madame de Staël och Sverige. Bidrag till Madame de Staëls biografi. Huvudsakligen efter hittills otryckta originalihandskrifter, Lund 1911, s. 1-50; A. Sore1, Mme de Staël, Paris 1890; oraz Z. Anusik, Dyplomacja szwedzka wobec kryzysu monarchii we Francji w latach 1787-1792, Łódź 2000, s. 125-127. 
Od chwili objęcia funkcji reprezentanta interesów króla Szwecji przy dworze wersalskim Erik Magnus Staël von Holstein nadsyłał do Sztokholmu interesujące depesze dyplomatyczne, w których odnotowywał wszystkie aktualne wydarzenia rozgrywajace się we Francji. W czasie, kiedy absolutna monarchia Ludwika XVI zaczęła się chwiać w posadach, jako arystokratyczny liberał i zięć Neckera sympatyzował $z$ opozycja możnych i parlamentów przeciwko poczynaniom rządu królewskiego. Na podstawie relacji Staëla von Holsteina bardzo dokładnie można odtworzyć przebieg tzw. rewolty uprzywilejowanych, rozpoczętej na zwołanym przez ministra finansów Charlesa Alexandre'a de Calonne'a Zgromadzeniu Notabli (luty-maj 1787 r.), które odrzuciło przedstawione mu do zatwierdzenia projekty reform. Następca Calonne'a, arcybiskup Tuluzy Étienne Charles Loménie de Brienne próbował uzyskać poparcie $\mathrm{w}$ parlamentach przez lekka modyfikację projektów swojego poprzednika. Te kategorycznie sprzeciwiły się jednak zmianie systemu podatkowego polegajacej na wprowadzeniu powszechnego podatku gruntownego. Wobec stanowczej opozycji parlamentów wiosną $1788 \mathrm{r}$. przeprowadzono gruntowna reformę sąownictwa firmowaną nazwiskiem strażnika pieczęci Charlesa François de Lamoignona. W odpowiedzi wybuchły zamieszki w Paryżu i kilku innych miastach. W prowincjach stanowych domagano się rezygnacji z przeprowadzonej w 1787 r. reformy stanów prowincjonalnych. W Delfinacie doszło do samowolnej restytucji miejscowych stanów w dawnym kształcie. W rezultacie tych wydarzeń w sierpniu 1788 r. arcybiskup Sens (Loménie de Brienne otrzymał tę godność w początkach 1788 r.) ogłosił zwołanie Stanów Generalnych na wiosnę następnego roku i podał się do dymisji. Wraz z jego ustapieniem załamała się ostatnia próba modernizacji państwa. Po odejściu Brienne'a do rządu królewskiego powrócił Jacques Necker. We wrześniu 1788 r. parlament paryski podjął uchwałę, że Stany Generalne będa obradować $w$ takim samym kształcie, jak te $z$ roku 1614 (trzy oddzielne izby stanowe $z$ równą liczba reprezentantów, głosujacce odrębnie i wyposażone w prawo veta wobec innych stanów). Ten stary model nie mógł jednak zadowolić burżuazji, która zwołanie Stanów Generalnych chciała wykorzystać do gruntownej reformy państwa. W tym momencie zaczął się rozpadać dotychczasowy sojusz opozycyjnej arystokracji i członków parlamentów z opozycyjną burżuazją. Zaczęła się formować tzw. partia patriotyczna żąajaca podwojenia reprezentacji stanu trzeciego i wprowadzenia 
głosowania indywidualnego. Necker $z$ kolei chciał zniesienia przywilejów podatkowych, ale obawiał się, że stany uprzywilejowane storpeduja tę reformę. Dlatego gotów był zgodzić się na podwojenie reprezentacji stanu trzeciego, ale głosowanie indywidualne pragnał ograniczyć jedynie do spraw finansowych. W grudniu 1788 r. Rada Królewska pod naciskiem Neckera zgodziła się na podwojenie reprezentacji stanu trzeciego. Sprawę trybu głosowania pozostawiono jednak w zawieszeniu. O jej przyszłości zdecydować mieli reprezentanci narodu wybrani na zgromadzeniach wyborczych szlachty, kleru i stanu trzeciego ${ }^{2}$.

Inauguracja obrad Stanów Generalnych w dniu 5 maja 1789 r. wywołała konsternację wśród deputowanych stanu trzeciego. W swoim trzygodzinnym, nudnym i przepełnionym liczbami przemówieniu, Jacques Necker nie wspomniał bowiem ani o sprawie głosowania indywidualnego, ani o kwestii reform politycznych. Zawiedzeni w swoich nadziejach posłowie przyjęli wystapienie ministra głuchym milczeniem. Jeszcze tego samego dnia przystapili też do narad, by zająć wspólne stanowisko wobec dalszych poczynań rządu. Konflikt między stanami rozpoczął się już 6 maja, kiedy reprezentanci duchowieństwa i szlachty zebrali się w przeznaczonych dla nich salach pałacu wersalskiego i rozpoczęli sprawdzanie pełnomocnictw, aby utworzyć oddzielne zgromadzenia stanowe. W tej sytuacji deputowani stanu trzeciego, którzy nie chcieli wyrazić zgody na głosowanie stanami, ale jednocześnie obawiali się otwartego wystapienia przeciwko tej zasadzie, poprzestali na wysunięciu żądania wspólnej weryfikacji mandatów i odmówili utworzenia oddzielnej izby. Następny miesiąc minął na bezpłodnych rokowaniach między debatujacymi oddzielnie stanami. Dnia 10 czerwca deputowani stanu trzeciego raz jeszcze zwrócili się do delegatów dwóch pierwszych stanów $z$ wezwaniem do rozpoczęcia wspólnych obrad, a gdy to nie dało rezultatu, 12 czerwca sami przystapili do weryfikacji mandatów, wyczytując kolejno nazwiska reprezentantów wszystkich trzech stanów wybranych w poszczególnych okręgach

${ }^{2}$ Relacje E.M. Staëla v. Holsteina $z$ lat $1787-1788$ por. Riksarkivet w Sztokholmie [dalej: RA], Gallica vol. 470 i 471, karty bez paginacji (uwaga ta dotyczy również wszystkich innych przywoływanych niżej zbiorów Riksarkivet). Bardzo szczegółowe i dokładne omówienie zasygnalizowanych tu zagadnień dotyczących polityki wewnętrznej Francji w okresie „rewolty uprzywilejowanych” por. J. Egret, La pré-révolution française (1787-1788), Paris 1962. Por. też Z. Anusik, op. cit., s. 132-152, 209-215. 
wyborczych. W ciagu kilku następnych dni kilkunastu proboszczów przyłączyło się do posłów stanu trzeciego. W tej sytuacji 17 czerwca 1789 r. deputowani reprezentujący stan trzeci ogłosili się Zgromadzeniem Narodowym i przyznali sobie prawo zatwierdzania wszystkich podatków ${ }^{3}$. Erik Magnus Staël von Holstein $z$ ogromną uwaga śledził wszystkie poczynania deputowanych do Stanów Generalnych. Od poczatku nie podobała mu się jednak atmosfera panująca w tym zgromadzeniu. Już 17 maja 1789 r. zauważył, że w Stanach Generalnych dominuja złe nastroje. Deputowani bardziej myśleli bowiem o własnych interesach niż o dobru publicznym. Bardziej pragnęli przeciwstawić się pomysłom innych, niż dążyć do wspólnego, konstruktywnego celu. Doskonale zorientowany w istocie sporu między stanami, szwedzki dyplomata podkreślał, że polega on na tym, że szlachta i wyższe duchowieństwo chciałyby głosować stanami, podczas gdy stan trzeci chciałby głosowania indywidualnego. W początkach czerwca Staël von Holstein pisał do Sztokholmu, że sytuacja $\mathrm{w}$ Wersalu daleka jest od przybrania pożądanego przez wszystkich obrotu. Jego zdaniem wina za niemożność ukonstytuowania się Stanów Generalnych leżała po stronie szlachty, która obawiajac się zamachu na swoje przywileje, wolała doprowadzić do jak największego zagmatwania spraw po to tylko, żeby odwlec chwilę, kiedy będzie musiała się zdobyć na jakieś poświęcenia. Bardzo ciekawa relację przesłał Staël do Sztokholmu 18 czerwca 1789 r. Pisał tu bowiem, że przed kilku dniami stan trzeci zaprosił szlachtę i kler do wspólnej weryfikacji pełnomocnictw. Ponieważ oba stany po raz kolejny odmówiły, deputowani stanu trzeciego ogłosili się Zgromadzeniem Narodowym. Zdaniem Staëla w ten sposób stan trzeci posunął się znacznie dalej, niż można było tego oczekiwać na podstawie dotychczasowych żądań narodu pod adresem króla. Ambasador przewidywał też, że przedstawiciele stanu trzeciego zechca zapewne wyrażać zgodę na podatki i dążyć będą do uchwalenia nowej konstytucji. Te zamiary, w opinii Staëla, mogłyby się jednak powieść tylko wówczas, gdyby szlachta zachowała całkowitą bierność i gdyby król nie zdecydował się na użycie siły wobec zbuntowanych deputowanych. Szwedzki dyplomata przypuszczał

${ }^{3}$ Por. A. Mathiez, La révolution française, t. I (La chute de la royauté 1787-1792), Paris 1928, s. 50-53; id e m, Rewolucja francuska, Warszawa 1956, s. 49-51; A. Sobou1, Rewolucja francuska, Warszawa 1951, s. 71-73; L. Vi11at, La révolution et l'Empire (1789-1815), t. I (Les Assemblées révolutionnaires 1789-1799), Paris 1947, s. 18-22. 
również, że Ludwik XVI nie uzna posłów stanu trzeciego za reprezentację całego narodu, ale nie będzie ich też zmuszał do zmiany przyjętej nazwy. Nawiązując do dyskutowanych powszechnie projektów reformatorskich, Staël von Holstein zauważył, że należy się spodziewać wielkiej fermentacji umysłów, jeśli król będzie musiał wybierać między projektem przygotowywanym przez reprezentantów stanu trzeciego a pomysłami wysuwanymi przez niechętnych jakimkolwiek zmianom arystokratów. Warto może podkreślić także fakt, że uchodzacy za zwolennika nadchodzacej rewolucji, Staël von Holstein $z$ pewnymi obawami patrzył na poczynania reprezentantów stanu trzeciego. Pisząc bowiem o zamierzonym zjednoczeniu sił szlachty, duchowieństwa i parlamentów, które wspólnie zamierzały przeciwstawić się żądaniom wysuwanym przez stan trzeci, doszedł do wniosku, że ten ostatni jest najbardziej niebezpieczny. $Z$ punktu widzenia władzy królewskiej spory między stanami nie miały jednak większego znaczenia. Według Staëla zasadnicze żądania wszystkich trzech stanów w kwestiach politycznych były bowiem niemal identyczne. Ostateczna konkluzja ambasadora nie była jednak zbyt optymistyczna. $Z$ wyraźnym potępieniem $z$ jego strony spotkały się bowiem zarówno dotychczasowe poczynania deputowanych do Stanów Generalnych, jak i coraz bardziej zdecydowana opozycja dworu wobec działań proponowanych przez Jacquesa Neckera. Swoją opinię o deputowanych wyraził następująco: „Pełne hipokryzji powątpiewanie kleru, zacięty upór szlachty i złość stanu trzeciego daja w sumie dość ponure widowisko". Całą relację zakończył zaś stwierdzeniem: „Nigdy jeszcze naród nie był usytuowany między takim złem a takim dobrem. $Z$ jednej strony głód, bankructwo, despotyzm i wojna domowa; $z$ drugiej pokój, wolność i potęga”.

Jest sprawą oczywistą, że zło reprezentowali w tym wypadku wrogowie Neckera, „ludzie bez zasad”, niemogący ścierpieć tego, że w Radzie Królewskiej zasiada człowiek, „który kieruje się tylko cnota i umiłowaniem dobra"4.

Tymczasem jednak sytuacja w coraz większym stopniu wymykała się spod kontroli rządu. Dnia 19 czerwca, po burzliwych debatach, nieznaczną większościa głosów duchowieństwo podjęło bowiem decyzję o przyłączeniu się do stanu trzeciego. Stało się jasne, że jeśli król nie przeszkodzi temu połączeniu, uprzywilejowani

${ }^{4}$ Por. E.M. Staël v. Holstein do Gustawa III, Paryż 17 V oraz 7 i 18 VI 1789, RA, Gallica vol. 472. Por też Corr. Staël-Holstein, ed. L. Leouzon Le Duc, Paris 1881, s. 101-103; Z. Anusik, op. cit., s. 217-218. 
poniosa klęskę. Tego samego dnia wieczorem monarcha podjął decyzję o unieważnieniu wszystkich uchwał przyjętych przez deputowanych stanu trzeciego na specjalnie zwołanym lit de justice. Nakazał też zamknać, pod pretekstem remontu, salę posiedzeń Stanów. Następnego dnia, 20 czerwca, deputowani stanu trzeciego zebrali się więc w Sali do Gry w Piłkę, gdzie złożyli przysięgę, że nie rozejdą się, zanim nie zostanie uchwalona konstytucja. W dwa dni później pięciu prałatów i 144 księży przyłączyło się do stanu trzeciego, powiększając w ten sposób liczbę członków Zgromadzenia Narodowego. Oczekiwane $z$ ogromnym napięciem „łoże sprawiedliwości” z 23 czerwca 1789 r. przyniosło klęskę tak królowi, jak i szlachcie. Ludwik XVI, unieważniając wszystkie dotychczasowe uchwały stanu trzeciego, nakazał deputowanym zachowanie podziału na trzy stany i obradowanie w osobnych izbach. Rozkaz królewski został jednak zignorowany przez reprezentantów nieuprzywilejowanych. Kiedy szlachta i część duchowieństwa opuszczały salę obrad, deputowani stanu trzeciego tkwili nieruchomo na swoich miejscach. Jeszcze tego samego dnia Zgromadzenie Narodowe potwierdziło powzięte wcześniej postanowienia i ogłosiło nietykalność swoich członków. Stan trzeci wkraczał więc na drogę otwartego buntu przeciwko monarchii. Król nie zdecydował się na użycie siły, a nieposłuszni deputowani pozostali na razie panami sytuacji ${ }^{5}$. Wszystkie te wydarzenia znalazły odzwierciedlenie w relacji Staëla von Holsteina z 25 czerwca 1789 r. Pisał on, że Necker usilnie zabiegał o kompromis między stanem trzecim a stanami uprzywilejowanymi. Według niego w piątek król zaakceptował przedstawiony mu przez ministra projekt ugody, korzystny dla stanu trzeciego. W niedzielę jednak bracia Ludwika XVI, Monsieur (Ludwik hrabia Prowansji) i Karol hrabia d'Artois, zostali powołani w skład Rady Królewskiej i natychmiast wprowadzili do projektu Neckera tak liczne poprawki, że stał się nie do przyjęcia dla Zgromadzenia Narodowego. W poniedziałek odbyło się następne posiedzenie Rady, na którym monarcha po raz kolejny zmienił zdanie, odrzucajac (zgodnie $z$ przewidywaniami Neckera) projekt ugody $z$ deputowanymi stanu trzeciego. Zdaniem Staëla to hrabia d'Artois doradzał Ludwikowi XVI kroki, które kompromitowały autorytet królewski, gdyż celem tych wszystkich zabiegów było zmuszenie Neckera do złożenia dymisji. Ambasador informował jednak dwór sztokholmski, że jego teść nie ma najmniejszego

\footnotetext{
${ }^{5}$ Por. A. Mathiez, Rewolucja..., s. 51-54; A. Sobou1, op. cit., s. 73-74.
} 
zamiaru odchodzić $z$ ministerium. $Z$ niekłamana satysfakcją pisał także o ogromnej popularności Neckera w Paryżu. Kiedy bowiem minister nie zjawił się na uroczystym posiedzeniu Stanów w dniu 23 czerwca, wywarło to tak wielkie wrażenie na opinii publicznej, że 2000 ludzi przyszło do króla z żądaniem zatrzymania Neckera w rządzie. W tej samej depeszy Staël informował Gustawa III, że większość kleru poprzedniego dnia przyłączyła się do Zgromadzenia Narodowego, a rankiem 25 czerwca naśladowało ich 47 przedstawicieli szlachty $z$ księciem Ludwikiem Filipem Orleańskim na czele. Chociaż zdecydowana większość szlachty i grupa hierarchów kościelnych w dalszym ciagu opowiadała się za oddzielnymi obradami, ambasador spodziewał się jednak ustępstw ze strony króla i jego ugody ze Zgromadzeniem Narodowym. Komentując zaś sprawę zatrzymania na jednej $z$ ulic stolicy karety arcybiskupa paryskiego, sprzeciwiającego się ustępstwom na rzecz stanu trzeciego, Staël napisał: „Jest przykre, że lud miesza się do tych spraw, ale skoro sprawy raz doszły do tego punktu, w którym obecnie się znajdują, to właśnie lud stał się suwerenem"6.

Ludwik XVI i jego arystokratyczni doradcy nie zamierzali rzecz jasna tolerować takiego stanu rzeczy. W dniu 26 czerwca wydano rozkazy, aby w okolice Wersalu i Paryża przybyło 20 tys. żołnierzy $z$ pułków cudzoziemskich. Dwór szykował się do rozpędzenia siła Zgromadzenia Narodowego. Chcąc jednak uśpić podejrzenia deputowanych, nazajutrz monarcha zwrócił się do wiernych sobie delegatów szlachty i duchowieństwa $z$ pisemnym wezwaniem do połączenia się ze Zgromadzeniem. Przygotowania wojskowe dworu doprowadziły jednak do wzburzenia w Paryżu. Sytuacja w mieście w coraz większym stopniu wymykała się spod kontroli rządu. Król nie panował również nad Zgromadzeniem, które 9 lipca 1789 r. ogłosiło się Zgromadzeniem Narodowym Ustawodawczym (Konstytuantą) ${ }^{7}$. Tego samego dnia Erik Magnus Staël von Holstein napisał w swojej depeszy, że $z$ niepokojem obserwuje dziwaczny spektakl, jakiego dostarcza niekonsekwencja i niezdecydowanie

${ }^{6}$ Por. E.M. Staël v. Holstein do Gustawa III, Paryż 25 VI 1789, RA, Gallica vol. 472; Corr. Staël-Holstein, s. 103-105. Por. też N. Åke s o n, Gustaf III: s förhållande till franska revolutionen, Bd I, Lund 1885, s. 17; A. Geffroy, op. cit., t. II, Paris 1867, s. 101; Z. Anusik, op. cit., s. 218-219.

7 Szerzej o zasygnalizowanych tu problemach por. A. Mathiez, Rewolucja..., s. 55-56; A. Soboul, op. cit., s. 74-77; J. Baszkiewicz, Ludwik XVI, Wrocław 1983, s. 215-217; R. Bielecki, Bastylia 1789, Warszawa 1991, s. 19-21; J. Godechot, La prise de Bastille. 14 Juillet 1789, Paris 1965, s. 226 i n. 
króla Francji. Jego krokami próbuje bowiem kierować z jednej strony Necker, $z$ drugiej zaś grupa intrygantów skupionych wokół Marii Antoniny i hrabiego d'Artois. Prowadzi to do tego, że Ludwik XVI akceptuje jakieś przedsięwzięcie tylko po to, aby wkrótce potem przychylić się do innego rozwiązania. Posuwa się naprzód bez żadnego planu działania, narażając się na krytykę ze wszystkich stron. Necker nie przestaje wyjaśniać królowi, że należy przyjąć spójny i jednoznaczny system polityczny, w którym zostana wykorzystane wszystkie możliwe środki mogące oddalić niebezpieczeństwo nadciagajacej nieubłaganie rewolucji. Zdaniem Staëla minister doradzał Ludwikowi XVI, aby zjednoczył się ze szlachtą, duchowieństwem i parlamentami. Niedawni opozycjoniści zdali sobie bowiem sprawę $z$ poniesionej klęski i $z$ coraz większym niepokojem spoglądali na to, co dzieje się w Stanach Generalnych. W przypadku przyjęcia takiej linii postępowania król powinien mianować nowego ministra, którego zasady byłyby zgodne $z$ powyższymi celami. O wiele bliższa sercu ambasadora była jednak druga propozycja przedstawiona przez jego teścia Ludwikowi XVI. W dalszej części cytowanej depeszy pisał on bowiem: „Jeśli jednak król obawiałby się strasznych nieszczęść, które mogłyby zostać spowodowane takim postępowaniem, należy otwarcie podzielić poglądy narodu i nie mogac zapobiec nadciagającej rewolucji, należy stanąć na jej czele po to, żeby nią pokierować”. Na nieszczęście jednak „żaden wielki ruch, ani dobry, ani też zły, nie leży w charakterze króla. Ogląda się on ostrożnie na obie strony, przyjmuje na przemian rady najbardziej przeciwne po to, by zrównoważyć jedne drugimi i pogodzić obie zwalczające się partie".

Zdaniem szwedzkiego dyplomaty było to błędne działanie, które prowadziło do znacznego obniżenia autorytetu królewskiego w oczach narodu. Komentując ostatnie wydarzenia Staël pisał, że jest rzecza pewna, że po lit de justice z 23 czerwca na dworze powstał projekt aresztowania 30 deputowanych i rozpędzenia całej reszty. Wydano też rozkazy w celu ściagnięcia do Wersalu oddziałów wojskowych, powierzając dowództwo nad nimi staremu marszałkowi, księciu Victorowi François de Broglie ${ }^{8}$.

Ambasador nie miał najmniejszych watpliwości, że był to projekt wymierzony przeciwko Stanom. Na szczęście jednak wystąpiły liczne przeszkody natury organizacyjnej, które uniemożliwiły wykonanie tego szkodliwego pomysłu. Staël von Holstein, w przeciwieństwie

${ }^{8}$ Por. E.M. Staël v. Holstein do Gustawa III, Paryż 9 VII 1789, RA, Gallica vol. 472. 
do króla, zdawał sobie sprawę $z$ nastrojów panujących $\mathrm{w}$ armii francuskiej, która jego zdaniem w przypływie złego humoru mogła zawieść pokładane w niej przez dwór nadzieje. W dalszej części swojej depeszy Staël pisał, że Zgromadzenie Narodowe $z$ inicjatywy Honoré Gabriela hrabiego de Mirabeau poprosiło króla o oddalenie oddziałów regularnej armii i powierzenie straży nad Paryżem gwardii mieszczańskiej. Ten krok Zgromadzenia bardzo nie spodobał się monarsze, który uznał go za wkraczanie w prerogatywy władzy wykonawczej. Zdaniem ambasadora największym problemem Ludwika XVI był jednak rozłam w Radzie Królewskiej, który uniemożliwiał podejmowanie właściwych decyzji. Według Staëla Jacques Necker, Armand Marc hrabia de Montmorin, François Emmanuel hrabia de Saint-Priest i Anne markiz de La Luzerne byli jedynymi ludźmi nie tylko w rządzie, lecz także na dworze, którzy chcieli postępować bez użycia przemocy i zgodnie $z$ zasadami dyktowanymi przez rozum i rozwagę. Wyrażajac ogromna obawę przed ściagającymi w okolice stolicy oddziałami cudzoziemskimi, ambasador miał jednak nadzieję, że niebiosa ustrzega Francję przed rzuceniem ich do akcji, „ponieważ straszne nieszczęścia, jakie byłyby następstwem użycia przeciwko Zgromadzeniu oddziałów wojskowych, nie przyniosa żadnego pożytku królowi. Umysły sa bowiem tak rozpalone, że nic nie może zatrzymać zbliżającej się rewolucji. Jeśli zaś dojdzie do jej wybuchu, należy się spodziewać wszelkich możliwych ekscesów".

Na zakończenie swojej relacji Staël pozwolił sobie wreszcie na wyrażenie opinii, że „otwarte wystąpienie przeciwko Zgromadzeniu może być dla narodu impulsem, który da mu energię, o brak której powszechnie się go oskarża". Szwedzki dyplomata nie mógł nawet przypuszczać, jak szybko miały się sprawdzić wszystkie jego przewidywania 9 .

Dnia 11 lipca 1789 r. Ludwik XVI zdymisjonował bowiem Jacquesa Neckera, powołujac na jego miejsce zdeklarowanego konserwatystę, Louisa Auguste'a Le Tonnelier barona de Breteuil. Następnego dnia wieść o dymisji popularnego ministra dotarła do Paryża, wywołując tam wstrząsajace wrażenie. Na znak protestu zamknięto giełdę i zawieszono przedstawienia teatralne. W różnych punktach miasta odbywały się spontaniczne zebrania i manifestacje. W ogrodach pałacu tuileryjskiego doszło też do starcia ludu $z$ pułkiem Royal Allemand, dowodzonym przez Charlesa Eugène'a księcia

9 Por. ibidem. Ta sama depesza por. Corr. Staël-Holstein, s. 105-107. Por. też Z. Anusik, op. cit., s. 219-221. 
de Lambesc $^{10}$. W pisanej 12 lipca depeszy do Sztokholmu Staël von Holstein poinformował swój dwór, że poprzedniego dnia o godzinie 3 po południu król napisał do Neckera, aby złożył swój urząd i wyjechał $z$ Francji w ciagu 24 godzin. Necker bez najmniejszego oporu skrupulatnie zastosował się do otrzymanego rozkazu. Staël przewidywał, że po dymisji jego teścia należy się spodziewać również innych zmian $\mathrm{w}$ ministerium. Jego zdaniem sprawczynią upadku Neckera była Maria Antonina. W związku z tym należało przypuszczać, że polityka zagraniczna Francji od tej pory będzie o wiele bardziej korzystna dla cesarza i dla Rosji. Ambasador nie był jednak pewien, czy poglądy królowej podziela następca Neckera - baron de Breteuil. Staël nie wróżył zresztą dobrze nowemu rządowi. W dalszej części cytowanej depeszy pisał bowiem: „Nowe ministerium, jeśli się utrzyma, będzie jednak wstrętne dla ludu. Fermentacja umysłów doszła zaś do takiego stopnia, że należy się obawiać wszystkiego najgorszego".

Wina za taki stan rzeczy szwedzki dyplomata obarczał Ludwika XVI, o którym pisał, że „jest nieskończenie godny pożałowania i niezmiernie trudno jest przewidzieć rozmiar nieszczęść, jakie jego słabość może ściagnąć na Francję"11.

Dnia 13 lipca rozruchy w Paryżu trwały. Gromady ludzi przebiegały ulice w poszukiwaniu broni. Zgromadzenie elektorów, które dokonało wyboru paryskich deputowanych do Stanów Generalnych, ze starymi władzami miejskimi utworzyło w ratuszu stały komitet. Ten $z$ kolei podjął decyzję o utworzeniu mieszczańskiej milicji - gwardii narodowej. Następnego dnia, 14 lipca 1789 r., tłum ruszył na Pałac Inwalidów, gdzie zdobył blisko 30 tys. strzelb. Mieszkańcy przedmieścia Saint-Antoine przypuścili zaś szturm na Bastylię, twierdzę będącą symbolem królewskiego absolutyzmu i tyranii, która po krótkim oporze skapitulowała. Upojony zwycięstwem lud zamordował komendanta Bastylii, markiza Bernarda René de Launaya i prewota kupców Jacquesa Flessellesa, których głowy, zatknięte na ostrzach pik, obnoszono w triumfie po ulicach

\footnotetext{
${ }^{10}$ Por. A. Mathiez, Rewolucja..., s. 56-57; A. Sobou1, op. cit., s. 77-78; L. Villat, op. cit., s. 31-32.

${ }^{11}$ Por. E.M. Staël v. Holstein do Gustawa III, Paryż 12 VII 1789, RA, Gallica vol, 472; Corr. Staël-Holstein, s. 107-108; A. Söder hj elm, Sverige och den franska revolutionen. Bidrag till kännedom om Sveriges och Frankrikes inbördes förhållande i slutet av 1700-talet, Bd I (Gustav III:s tid), Stockholm 1920, s. 197-198; Z. Anusik, op. cit., s. 222.
} 
miasta. Ku zaskoczeniu wszystkich dwór zachował całkowitą bierność wobec tych wypadków. Dowodzący oddziałami królewskimi stojącymi na Polach Marsowych baron Pierre Victor de Besenval nie ośmielił się wkroczyć do Paryża i wydał swoim żołnierzom rozkaz do odwrotu. Zachęceni bezczynnością rządu, w dniu 15 lipca paryscy elektorzy powołali Jeana Sylvaina Bailly'ego na stanowisko mera stolicy i wezwali markiza Marie Josepha de La Fayette'a do objęcia dowództwa gwardii narodowej. Bezpośrednim, aczkolwiek dość niespodziewanym, następstwem tych wydarzeń była kapitulacja Ludwika XVI, który jeszcze tego samego dnia zjawił się w Zgromadzeniu Narodowym, aby poinformować deputowanych o odwołaniu wojska. W dniu 16 lipca król usunął z rządu Breteuila i przywołał z powrotem Neckera. Nazajutrz zaś monarcha przybył osobiście do paryskiego ratusza, by usankcjonować swoją obecnością wyniki rewolucji ludowej. Miara jego poniżenia było przyjęcie $z$ rąk mera Bailly'ego symbolu rewolucji - trójkolorowej kokardy. Oburzeni kapitulancka postawą króla, nieprzejednani arystokraci $z$ hrabią d'Artois i księciem Kondeuszem na czele zdecydowali się na opuszczenie granic Francji, zapoczątkowując w ten sposób ruch emigracyjny ${ }^{12}$. Co ciekawe, wszystkie te wydarzenia nie znalazły jakiegokolwiek odzwierciedlenia w bieżacych relacjach Staëla von Holsteina. Do wypadków lipcowych odniósł się bowiem dopiero kilka miesięcy później. Na razie, w dopisku do depeszy z 19 lipca, ambasador poinformował Gustawa III jedynie o wyjeździe hrabiego d'Artois do Holandii i przywróceniu Neckera na stanowisko generalnego kontrolera finansów ${ }^{13}$.

Tymczasem sytuacja we Francji uległa dalszemu zaostrzeniu. Przykład Paryża naśladowały bowiem miasta prowincjonalne. Niemal wszędzie powoływano nowe zarządy municypalne i tworzono mieszczańskie milicje. Królewscy intendenci podejmowali współpracę $z$ władzami lokalnymi lub też opuszczali swoje stanowiska. Rząd centralny stracił jakikolwiek wpływ na bieg wypadków. Na domiar złego 20 lipca w Île-de-France rozpoczęły się wielkie rozruchy chłopskie (zwane „Wielka Trwoga”), które rozszerzając się z ogromną szybkościa, wkrótce dotarły do najdalszych krańców

12 Szerzej o wzmiankowanych tu wydarzeniach por. A. Mathiez, Rewolucja.., s. 57-59; A. Soboul, op. cit., s. 78-79; R. Bielecki, op. cit., s. 22-102; J. Godechot, op. cit., s. 227-323; L. Villat, op. cit., s. 34-39.

13 Por. E.M. Staël v. Holstein do Gustawa III, Paryż 19 VII 1789, apostille, RA, Gallica vol. 472. 
Francji. Niepokoje nie ominęły także stolicy, gdzie w dniu 23 lipca radca stanu Joseph François Foullon i jego zięć, intendent Paryża Louis Benigné François Berthier zostali powieszeni na latarni przy ratuszu ${ }^{14}$. Obserwując $z$ napięciem wszystkie te wydarzenia, 2 sierpnia 1789 r. Erik Magnus Staël von Holstein pisał, że nie widać końca nieporządków, jakie panują tak w Paryżu, jak i w całej Francji. Podkreślał fakt, że władza wykonawcza została niemal definitywnie wyrwana $z$ rąk króla, czego smutnym następstwem jest całkowita anarchia panująca zarówno w stolicy, jak i na prowincji. Odnotowujac zabiegi podjęte przez Neckera, który zmierzając do uspokojenia sytuacji w stolicy, usiłował doprowadzić do ogłoszenia ogólnej amnestii i uwolnienia aresztowanego przez władze municypalne barona de Besenval. Ambasador był jednak przekonany, że zakończą się one niepowodzeniem. Pisał bowiem do Gustawa III, „że zarówno lud, jak i Zgromadzenie Narodowe zamierzaja $z$ całą surowościa traktować wszystkie osoby, które opinia publiczna uważa za sprawców swoich nieszczęść"15.

Nie mogąc się zdecydować na użycie królewskich żołnierzy przeciwko zbuntowanym chłopom, Zgromadzenie Narodowe postanowiło doprowadzić do uśmierzenia rozruchów w inny sposób. Na słynnym posiedzeniu w nocy z 4 na 5 sierpnia 1789 r., w atmosferze ogólnego uniesienia, deputowani $z$ uprzywilejowanych prowincji stanowych, delegaci poszczególnych miast, szlachta i księża składali kolejno „na ołtarzu ojczyzny” swoje stare przywileje. W ciagu jednej nocy ustanowiono zasadę równości wobec prawa, doprowadzając też do politycznego i administracyjnego zjednoczenia całego państwa. W ten sposób zrealizowano zadanie, z którym od dawna bezskutecznie borykała się monarchia absolutna. Na gruzach dawnego porządku można było przystapić do wznoszenia nowej budowli. Tymczasem zaś wieści o nocnych uchwałach Zgromadzenia rozeszły się błyskawicznie po kraju, doprowadzając w krótkim czasie do pacyfikacji nastrojów. Chłopi przestali palić zamki, pojmując dosłownie pierwsze zdanie dekretu, w którym stwierdzano, że „Zgromadzenie Narodowe całkowicie znosi ustrój feudalny”.

${ }^{14}$ Por. A. Mathiez, Rewolucja..., s. 60-63; A. Sobou1, op. cit., s. 79-82; L. Villat, op. cit., s. 39-42. Szerzej o wydarzeniach na francuskiej prowincji por. G. Lefebvre, La grande peur de 1789, Paris 1932; oraz idem, The Great Fear of 1789: Rural panic in revolutionary France, introd. G. Rudé, New York 1989.

15 Por. E.M. Staël v. Holstein do Gustawa III, Paryż 2 VIII 1789, RA, Gallica vol. 472; Corr. Staël-Holstein, s. 108. Por. też Z. A nu sik, op. cit., s. 223-224. 
Na mocy wydanych między 5 a 11 sierpnia 1789 r. rozporządzeń wykonawczych do tego dekretu zniesiono jednak tylko swiadczenia ciążące na osobie chłopa. Ciężary spoczywające na ziemi chłopskiej (czynsze, renty, daniny) miały zostać utrzymane aż do chwili ich ostatecznego wykupu. Również dziesięcina miała być pobierana od chłopów aż do czasu przeprowadzenia reformy kościelnej ${ }^{16}$.

Komentując wszystkie te wydarzenia w depeszy z 9 sierpnia, Staël von Holstein zauważył, że w nocy $z 4$ na 5 sierpnia Stany Generalne (ambasador w dalszym ciągu używał tej nazwy) uczyniły olbrzymi krok w kierunku równości, do której stan trzeci wydawał się od tak dawna tęsknić. Szwedzki dyplomata $z$ niepokojem obserwował jednak rozwój wydarzeń na francuskiej scenie politycznej. Uważał bowiem, że Francja wkroczyła w rewolucję, której nie da się $z$ niczym porównać. Rewolucja francuska była, w jego przekonaniu, wyjątkowa ze względu na szybki bieg wydarzeń i ogromną wagę zmian, do których prowadziła. Już wówczas Staël sformułował również bardzo trafne, jak się miało okazać, przypuszczenie, że wkrótce rewolucja ta doprowadzi do krwawych porachunków między zwalczającymi się ugrupowaniami. Otwarcie przyznawał, że jest w swoich pogladach odosobniony, gdyż wszyscy inni obserwatorzy francuskiej sceny politycznej uważali, że niebawem nastąi uspokojenie i sprawy wrócą do naturalnego porzadku. Obawy ambasadora budziły jednak trzy zasadnicze kwestie. Po pierwsze, wyjazd $z$ kraju książąt krwi i wielu innych znaczących osobistości, które nie zamierzały pogodzić się z nowymi porządkami. Po drugie, ogromne niezadowolenie wielu arystokratów ze zmian, które ostatnio nastąiły. Po trzecie wreszcie, swawola ludu i jego szalone żądania, tak absurdalne, że niemożliwe do zaspokojenia. Staël był także głęboko przekonany o tym (jak najbardziej słusznie!), że król i królowa uważają, że poświęcenia, do których zostali ostatnio zmuszeni, sa tylko tymczasowe i wymuszone przez potrzebę chwili. Wyciagał stąd wniosek, że w przyszłości para monarsza dążyć będzie do restytucji silnej władzy królewskiej. Wszystkie te obserwacje skłaniały go do stwierdzenia, że w najbliższym czasie we Francji nie należy się spodziewać powszechnego pojednania ${ }^{17}$.

16 Por. A. Mathiez, Rewolucja..., s. 63-66, 67-70; A. Soboul, op. cit., s. 82-85; L. Villat, op. cit., s. 44-46.

17 E.M. Staël v. Holstein do Gustawa III, Paryż 9 VIII 1789, RA, Gallica vol. 472; Corr. Staël-Holstein, s. 108-110. Por. też Z. Anu sik, op. cit., s. 224-225. 
Dnia 13 sierpnia 1789 r. Staël von Holstein pisał o dalszych pracach Zgromadzenia Narodowego, które zajęło się sprawą przywilejów stanu duchownego. Zdaniem ambasadora kler wbrew własnej woli został zmuszony do daleko idących ustępstw, a jego poświęcenie w dużym stopniu spowodowane było obawami przed reakcja paryskiej ulicy. W tej samej depeszy Staël zwracał także uwage na brak we Francji jakiejkolwiek władzy wykonawczej i silną opozycję części Zgromadzenia Narodowego przeciwko rządowi. W jego przekonaniu hrabia de Mirabeau, ksiądz Emmanuel Joseph Sieyès i ich dość liczni zwolennicy chcieliby zredukować władzę królewska do jak najmniejszych rozmiarów. Opinia publiczna była pewna, że działaniami tej partii kieruje skrycie książę Ludwik Filip Orleański, ale ambasador nie przypuszczał, żeby był on do tego zdolny. Największe obawy szwedzkiego dyplomaty budził jednak fakt, że Zgromadzenie dokonało tak licznych poprawek w nowym projekcie finansowym przedstawionym mu przez Neckera, „że będzie to oznaczało śmiertelny cios dla kredytu"18.

W dniu 26 sierpnia 1789 r. Zgromadzenie Narodowe uchwaliło słynną „Deklarację Praw Człowieka i Obywatela”, pomyślaną jako wstęp do przyszłej konstytucji ${ }^{19}$. Co ciekawe, sprawa ta nie wzbudziła większego zainteresowania Staëla von Holsteina. W swojej depeszy z 29 sierpnia informował Gustawa III jedynie o tym, że nie może wręczyć jego przyjaciółce, pani de Boufflers przeznaczonej dla niej korespondencji, gdyż zaraz na początku rewolucji wyjechała ona $z$ Paryża. Pisał także, że sprawy wewnętrzne we Francji przybrały obrót najbardziej poważny i najbardziej fatalny. Po wielkich katastrofach, które przetoczyły się przez ten kraj w ostatnim czasie, należałoby spodziewać się pewnego uspokojenia. Nie mogło ono

18 Por. E.M. Staël v. Holstein do Gustawa III, Paryż 13 VIII 1789, RA, Gallica vol. 472; Corr. Staël-Holstein, s. 110-111. Sytuacja finansowa Francji była w tym czasie rzeczywiście katastrofalna. W swoim wystapieniu w Zgromadzeniu Narodowym w dniu 7 VIII 1789 r. Necker proponował podwyższenie podatków i rozpisanie nowej pożyczki na $30 \mathrm{mln}$ liwrów oprocentowanej na $5 \%$. Zgromadzenie wyraziło swoją zgodę jedynie na pożyczkę, obniżając jednocześnie jej oprocentowanie do $4 \%$. Po 20 dniach okazało się, że udało się sprzedać obligacje jedynie za 2,5 mln liwrów. Dnia 27 VIII Necker zaproponował więc rozpisanie pożyczki na $80 \mathrm{mln}$ liwrów. Tym razem jednak w ogóle nie udało się znaleźć nabywców na papiery państwowe. Kredyt ministra został więc całkowicie wyczerpany, a jego popularność w społeczeństwie ogromnie spadła. Por. L. Villat, op. cit., s. 50. Szerzej o działalności Neckera w tym czasie por. J. Egret, Necker, ministre de Louis XVI. 1776-1790, Paris 1978.

19 Por. A. Sobou1, op. cit., s. 85, 98-99; A. Mathiez, Rewolucja..., s. 72-74; L. Villat, op. cit., s. 46-49. 
jednak nastapić, gdyż - zdaniem Staëla - istniała grupa ludzi, która zmierzała do pogłębienia obecnych trudności. Opinia publiczna była przekonana, że książę Orleański stoi na czele tej strasznej partii. Sam ambasador zdawał się przychylać do tych poglądów, zwracając jednocześnie uwagę na fakt, że upadek dyscypliny w wojsku, kłopoty rządu $z$ uzyskaniem nowych kredytów i zapewnieniem dostatecznej ilości zboża na zaopatrzenie stolicy potęgują panująca anarchię i stwarzają źle usposobionym okazję do planowania kolejnych przewrotów. Staël odnotował także pogłoski, że Anglia robi wszystko, aby spotęgować trudności Francuzów. Wydawało mu się również wielce prawdopodobne, że książę Orleański działa w porozumieniu $z$ dworem londyńskim, wciagając do współpracy dawnego ministra - Charlesa Alexandre'a de Calonne'a. Swoje wywody Staël von Holstein zakończył zaś następującym stwierdzeniem: „Mamy wielkie szczęście, Najjaśniejszy Panie, że nasze dawne związki polityczne z Francja zostały zerwane. Należy bowiem uważać to państwo (jeżeli w ogóle kiedykolwiek wydobędzie się $z$ okropnego kryzysu, w jakim obecnie się znajduje) za wykreślone na wiele lat $z$ rzędu mocarstw europejskich".

Dnia 29 września 1789 r. depesza ambasadora dotarła do Gustawa III, przebywającego ówcześnie w fińskiej miejscowości Lovisa. Jeszcze tego samego dnia król sporządził na niej, przeznaczoną dla sekretarza stanu do spraw zagranicznych, Ulrica Gustafa Franca notatkę: „Trzeba uprzedzić Staëla, żeby sporządził dla nas szczegółowy spis wszystkich przywódców różnych partii, $z$ informacją o ich projektach i ich talentach. Chcemy także wiedzieć jak najwięcej o aktualnej sytuacji króla, jego żony, braci oraz starych i nowych ministrów"20.

Gustaw III, od dłuższego już czasu obserwujący $z$ napięciem rozwój wypadków we Francji, latem 1789 r. z coraz większym niepokojem zdawał się bowiem przyjmować wieści napływające $z$ kraju, rządzonego przez władcę, którego przez wiele lat uważał za swego najbliższego sojusznika.

W ostatnich dniach sierpnia 1789 r. doniesienia Staëla von Holsteina w dalszym ciagu przesiąknięte były daleko idącym pesymizmem. Pisał bowiem, że Konstytuanta chce okroić władzę królewską prawie do zera, a w kraju nadal panuje ogromne wzburzenie. Winnym całego zamieszania miał być - zdaniem Staëla - Ludwik XVI,

${ }^{20}$ Por. E.M. Staël v. Holstein do Gustawa III, Paryż 29 VIII 1789 oraz notatka Gustawa III na tej depeszy, RA, Gallica vol. 472; Corr. Staël-Holstein, s. 111-113. Por. też A. Söderhjelm, op. cit., s. 200; Z. Anusik, op. cit., s. 226. 
który w początkach rewolucji podjął szereg błędnych decyzji. Ambasador miał jednak nadzieję, że rozsądek i mądrość Neckera zdołają doprowadzić do umiarkowania egzaltowane pomysły Zgromadzenia. Minister robił bowiem wszystko, co w jego mocy, aby zachować dla króla tyle władzy, ile powinien mieć monarcha. W tej samej depeszy Staël pisał, że Szwajcarzy prawdopodobnie opuszczą służbę francuska. Zapewniał też swojego władcę, że będzie się starał zaciagnąć kilka ich pułków do służby szwedzkiej. Co wydaje się jednak najbardziej nieprawdopodobne, w tym samym liście ambasador prosił Gustawa III o zgodę na wyjazd $z$ Paryża na okres dwa-trzy miesiace w celu poratowania zdrowia w Szwajcarii, obiecując wrócić na swój posterunek, jak tylko wydarzy się we Francji coś istotnego ${ }^{21}$. Na razie jednak Staël siedział w Paryżu i kontynuował swoja korespondencję $z$ dworem sztokholmskim. W dniu 3 września pisał w swojej kolejnej depeszy, że przez Ulrica Gustafa Franca otrzymał rozkaz królewski nakazujaccy mu przedstawienie obrazu aktualnych stosunków Francji z Hiszpanią i opisanie stanu państwa francuskiego. Zwłaszcza to drugie zadanie uznał za niezmiernie trudne ze względu na złożoną sytuację, w jakiej znalazła się w ostatnim czasie Francja. Nie pozostało mu więc nic innego, jak uciec się do przypuszczeń, które w jego przekonaniu, były jedynym sposobem, za pomoca którego można było pokusić się o wyrażenie opinii w sprawie przyszłości państwa francuskiego. Pisał więc Staël, że jeśli konstytucja będzie taka, jakiej życzy sobie najzdrowsza część narodu, czyli inaczej mówiąc, zachowa w rękach króla silną władzę wykonawczą i przyzna mu veto absolutne w stosunku do wszystkich nowych ustaw, to w takim wypadku sojusz z Hiszpanią pozostanie nienaruszony. Jeśli jednak różne kabały i śmieszne pretensje ze strony Stanów Generalnych [Konstytuanty] odsuną króla od wszystkiego, to wydaje się, że wtedy dwór hiszpański, jeśli zostanie o to poproszony przez dwór wersalski, zechce podtrzymać monarchię francuską i uchronić ją przed niebezpieczeństwami targającej nią obecnie burzy. Trudno jednak przewidzieć, jakie będa faktyczne następstwa aktualnego nieporządku. Trzeba poczekać na

${ }^{21}$ Por. E.M. Staël v. Holstein do Gustawa III, Paryż 30 VIII 1789, RA, Gallica vol. 472 . 13 X 1789 r. Gustaw III sporządził na tej depeszy notatkę dla U.G. Franca. Zgodnie $z$ poleceniem króla Staël miał kontynuować rokowania w sprawie wynajęcia pułków szwajcarskich. Władca zgadzał się również na jego wyjazd do Szwajcarii pod warunkiem, że wróci do Paryża w styczniu następnego roku. Por. ibidem. Por. też Corr. Staël-Holstein, s. 113. 
uchwalenie konstytucji, żeby móc wnioskować, jak wielki wpływ naród francuski będzie miał na zobowiazzania polityczne, jakie jego król chciałby przyjąć w stosunku do swoich sojuszników. W opinii ambasadora była jednak sprawa, która $z$ cała pewnościa musiała $\mathrm{w}$ przyszłości doprowadzić do konfliktu dworu $z$ narodem. $Z$ dużą dozą przenikliwości przewidywał, że dwór będzie zmuszony do wyrzeczenia się wszelkich związków z Domem Austriackim. Stara niechęć Francuzów do Austriaków została bowiem w ostatnim czasie spotęgowana przez niewyobrażalną wręcz nienawiść ludu do królowej, uważanej powszechnie za przyczynę wszelkiego zła, które dotknęło Francję. W tej samej depeszy Staël informował króla, że ujawniono wysokość długów hrabiego d'Artois, które wynoszą 19 mln liwrów. Nie spodziewano się, że będzie to suma tak ogromna, zwłaszcza po tym, jak Calonne spłacił wszystkich wierzycieli hrabiego niedługo przed swoim ustapieniem $z$ ministerstwa. W trzy dni później Staël pisał, że w Zgromadzeniu Narodowym dyskutuje się sprawę królewskiego veta, ale bez nadziei na podjęcie jakiejś konstruktywnej decyzji. W tej samej depeszy wyraził również opinię, że Maria Antonina utraciła w ostatnim czasie wszelki wpływ na sprawy państwowe i bliska wypełnienia wydaje się przepowiednia, że nieszczęścia tej władczyni nigdy się nie skończą ${ }^{22}$.

W relacji pisanej w dniu 13 września 1789 r. Erik Magnus Staël von Holstein podją próbę wyjaśnienia tego, co w ostatnim czasie wydarzyło się we Francji. Tekst ten wydaje się na tyle interesujący, że pozwolę sobie przytoczyć go w obszerniejszym nieco streszczeniu. Wyrażając na początku swojego wystapienia opinię, że rewolucja we Francji jest wydarzeniem godnym umieszczenia na zawsze w annałach całego świata, Staël pisał dalej, że aby wyjaśnić przyczyny tych nadzwyczajnych wypadków, trzeba się cofnąć do czasów ministerium arcybiskupa Sens. Tam znajdziemy bowiem oznaki rewolucji, której już wtedy należało się spodziewać. Fatalny stan finansów, jaki zastał ten minister, wymusił na nim podjęcie wielu wysiłków w celu zapełnienia królewskiej szkatuły. Wszystkie podjęte przez niego działania były jednak źle pomyślane i źle realizowane. Pociągnęły też za sobą opłakane rezultaty, doprowadzając w konsekwencji do poniżenia autorytetu królewskiego. Chciano się za wszelką cenę przypodobać narodowi, ale nie prowadziło to do niczego innego, jak do poniechania dzieła prawdziwych reform. Obietnice, o których

${ }^{22}$ Por. E.M. Staël v. Holstein do Gustawa III, Paryż 3 i 6 IX 1789, RA, Gallica vol. 472; Corr. Staël-Holstein, s. 113-115. Por. też Z. A nu si k, op. cit., s. 232-233. 
wiadomo, że nie zostaną nigdy zrealizowane, nie powinny być nigdy składane. Wkrótce też dobra wola ministra stała się podejrzana, dowiedziano się o jego słabości i niezręczności, po czym natychmiast przyszło powszechne lekceważenie. W tej sytuacji wszystkie poczynania arcybiskupa musiały okazać się bezowocne. Promyczek nadziei pojawił się w chwili, kiedy Necker wszedł do ministerium. Aczkolwiek król i królowa zostali zmuszeni do jego ponownego przywołania, to jednak wydawało się oczywiste, że własny interes skłoni ich do powierzenia się bez zastrzeżeń człowiekowi, którego powołano do ministerium tylko $z$ powodu wielkiego niebezpieczeństwa, w jakim znalazło się państwo. Brak pełnego zaufania ze strony pary królewskiej okazał się jednak głównym nieszczęściem nowej administracji Neckera. W końcu okoliczności zmusiły go do zwołania Stanów Generalnych. Król, królowa i hrabia d'Artois od początku byli przeciwni podwojeniu reprezentacji stanu trzeciego. Jednak to właśnie w ten sposób udało się zmusić uprzywilejowanych do płacenia podatków. Podwajając reprezentację stanu trzeciego, powiększono też siły partii królewskiej, dając władcy obrońców w postaci najliczniejszej części narodu. Parlamenty, intryganci dworscy i uprzywilejowani stali się przyczyna pierwszych niepokojów. Necker chciał wzmocnienia państwa i autorytetu królewskiego. Hrabia d'Artois uznal jednak, że powinien bronić wszystkich bez wyjątku przywilejów szlacheckich. Królowa w tajemnicy popierała przeciwników Neckera. Działała w ten sposób wbrew swoim własnym, prawdziwym interesom ${ }^{23}$.

Otwarcie Stanów Generalnych nastapiło pod złymi auspicjami. Panowały wojownicze nastroje wśród szlachty i partii dworskiej. Większość miast była oddana królowi i szukała jego protekcji. Postępowanie króla, arystokratów i wrogów Neckera zraziło jednak mieszczan do dworu. Opór szlachty przeciwko wspólnej weryfikacji pełnomocnictw zmusił zaś stan trzeci do ogłoszenia się Zgromadzeniem Narodowym. Dwór okazał niezdecydowanie i popełniał kolejne błędy. Starano się zmusić Neckera do odejścia z rządu. Tymczasem w Zgromadzeniu panowało wielkie rozbicie. Bardzo rozbieżne były bowiem interesy wszystkich trzech stanów. Potrzebna więc okazała się interwencja królewska. „Łoże sprawiedliwości”, na którym miano odczytać mądrą deklarację Neckera, nie przyniosło jednak spodziewanego rezultatu. Hrabia d'Artois torpedował bowiem pomysły

${ }^{23}$ Por. E.M. Staël v. Holstein do Gustawa III, Paryż 13 IX 1789, RA, Gallica vol. 472. 
ministra i postanowił wprowadzić zasadnicze zmiany do tekstu przygotowanej przez niego, bardzo korzystnej dla stanu trzeciego deklaracji. Necker, Saint-Priest i Montmorin mówili królowi o niebezpieczeństwie, na jakie się naraża, wprowadzając zmiany do pierwotnego tekstu generalnego kontrolera finansów. Wieczorem na Radzie przyjęto jednak projekt hrabiego d'Artois. Lit de justice, które odbyło się 23 czerwca, ujawniło cała absurdalność postępowania, do którego skłoniono monarchę. Stracił on bowiem całe zaufanie i popularność, jaką cieszył się dotąd wśród reprezentantów stanu trzeciego. Po powrocie do pałacu wręczono dymisję Neckerowi, który nie był obecny na posiedzeniu. Posłuszny otrzymanym rozkazom, Necker natychmiast wyjechał do Paryża. Następnego ranka 100 deputowanych i ogromna liczba ludu zgromadziła się jednak przed pałacem generalnego kontrolera, żądając jego powrotu do rządu. Wśród entuzjazmu ludu przywrócono Neckerowi jego poprzednie stanowisko. Była jeszcze wówczas niewielka nadzieja na przezwyciężenie kryzy$\mathrm{su}$, ale niestety, całkowicie zawiodła. Intryganci i wrogowie ministra rozpoczęli bowiem prawdziwą nagonkę przeciwko niemu. Jego czysty i prawy charakter zwiększał tylko liczbę jego wrogów. Król z pomoca marszałka de Broglie podjał przygotowania do zbrojnego rozwiazania nabrzmiałych problemów. Tymczasem jednak ze wszystkich stron narastała coraz większa opozycja i zwiększało się wzburzenie w całym kraju. Nie można było liczyć na wierność gwardii francuskiej. Necker zaproponował królowi, by obiecać paryżanom powołanie gwardii mieszczańskiej, przy zarezerwowaniu dla władcy nominacji wszystkich oficerów. Proponował też odesłanie armii marszałka de Broglie, której obecność wywoływała niezadowolenie opinii publicznej. Przez swoje kolejne decyzje monarcha powiększał jednak tylko niezadowolenie stanu trzeciego. Kiedy wreszcie Necker spostrzegł, że żadna $z$ jego rad, których tysiące każdego dnia dawał królowi, nie jest wprowadzana w życie, poczuł się zobowiazany do przedstawienia władcy opinii, że jego sumienie nie pozwala mu na zachowanie milczenia wobec niebezpieczeństw, na jakie wystawione będzie państwo, jeśli nie zostanie wprowadzony w życie jego plan. Jeśli zaś nie będzie mógł realizować swoich pomysłów, nie pozostanie mu nic innego, jak tylko poprosić króla o zgodę na swoja rezygnację. Necker chciał pozostać w rządzie, ale tylko pod warunkiem, że kroki, które zamierza podjąć, nie będą przez nikogo zmieniane ${ }^{24}$.

${ }^{24}$ Por. ibidem. 
Postawiony wobec takiej alternatywy, Ludwik XVI nie potrafił wybrać między żoną i bratem a ministrem. Necker zdecydował się też ostatecznie nie żądać dymisji, żeby nie spowodować kolejnego wzburzenia opinii publicznej. Tymczasem jego sytuacja na dworze stawała się jednak coraz trudniejsza. Zwiększała się liczba otwartych i sekretnych wrogów ministra, do których w pierwszym rzędzie zaliczały się ciotki króla oraz książęta Louis Joseph de Condé i Louis François de Conti, baron de Breteuil, książę Paul François de La Vauguyon, cała rodzina Polignaców, książę Anne Charles de Montmorency-Luxembourg, markiz Jean Thérèse d'Autichamp, zwolennicy wykonania planów marszałka de Broglie, a także wszystkie damy dworu, od dawna nienawidzące Neckera i pracujące nad jego oddaleniem. Markiz Marc Marie de Bombelles, ambasador Francji w Wenecji, przyjaciel Breteuila, został użyty do zapośredniczenia ugody pomiędzy baronem a księżna de Polignac. La Vauguyon intrygował, książę de Condé szukał sławy. Conti dostrzegał korzyści $z$ utrzymania Neckera u władzy, ale był zbyt uzależniony od parlamentów, za przywódcę których miał zaszczyt być uważanym. Ciotki króla chciały wprowadzić do rządu Josepha François Foullona. Były minister, Charles de Calonne, wsparty poparciem ze strony Polignaców i swojego przyjaciela, Josepha Hyacinthe'a Voudreuila rozpowszechniał swoja doktrynę wśród arystokratów. Baron de Breteuil, któremu hazard pozwolił wejść $z$ honorem do ministerium sądził, że nie będzie potrzebował niczego więcej, żeby zwiększyć swoją potęgę, gdyż do tej pory szczęście zawsze mu sprzyjało. Tak wyglądał najważniejszy człowiek nowej administracji. Jemu też powierzono zadanie zdobycia niezbędnych funduszy, ponieważ brak pieniędzy był największą przeszkoda w realizacji planów snutych przez wrogów dotychczasowego ministra. Ponieważ zaś Breteuil nie znał się na finansach, postanowił zwrócić się o pomoc do Jeana Pierre'a Louisa barona de Batz, awanturnika, który zdobył fortunę w czasie administracji arcybiskupa Sens. Batz obiecał Breteuilowi $100 \mathrm{mln}$ liwrów, ale na tę sumę chciał wypuścić oprocentowane papiery państwowe, nie widząc innego sposobu zdobycia pieniędzy. Marszałek Victor François de Broglie, który dowodził wojskiem, obiecał wszystko uśmierzyć. Zgodnie $z$ pierwotnie uzgodnionym planem postanowiono założyć wielki obóz wojskowy, do którego miał się udać król po opuszczeniu Wersalu. Stamtąd władca miał polecić Stanom Generalnym [Konstytuancie], aby podporządkowały 
się jego woli, a w przypadku napotkania najmniejszego nawet sprzeciwu, miał nakazać rozwiązanie Zgromadzenia Narodowego i aresztowanie tych spośród jego członków, którzy stawialiby największy opór. Necker także miał zostać aresztowany i planowano nawet wytoczenie mu procesu w parlamencie paryskim. W celu zmuszenia do posłuszeństwa mieszkańców Paryża zamierzano wprowadzić do miasta wojsko $z$ silna artylerią. Ministrowie dostali rozkaz rozpowszechniania wśród ludu druków, że to Necker jest odpowiedzialny za drożyznę chleba, ponieważ narzucał ludowi nowe podatki i przez swoja politykę doprowadził do powiększenia obszaru nieużytków. Spiskowcy, $z$ niecierpliwościa czekający na odpowiednią chwilę, aby skłonić króla do odwołania Neckera, nie wzięli jednak pod uwage ogromnego niezadowolenia panującego w armii. Obóz wojskowy nie mógł zostać uformowany, gdyż żołnierze każdego dnia opuszczali swoje sztandary. Wielki plan został więc ograniczony do najważniejszego punktu, jakim było oddalenie Neckera. Nakłoniono władce, żeby napisał do niego $z$ żądaniem jego dymisji. Pan de La Luzerne doręczył ministrowi ten list o godzinie 3. Trzy godziny później Necker opuścił Wersal. Dwóch gwardzistów śledziło trasę jego przejazdu. Nie wiadomo jednak, jakie mieli rozkazy i jakie były ich zamiary. W zakończeniu cytowanej depeszy Staël von Holstein w całej rozciągłości potwierdził, powszechne dziś przekonanie, o konserwatywnym charakterze poglądów swojego teścia. Jego zdaniem cały plan Neckera polegał bowiem na tym, że chciał on przede wszystkim doprowadzić do naprawy finansów. Gdyby mu się to udało, zamierzał następnie przywrócić zachwiany porządek w państwie, podtrzymując we wszystkim jego integralność i zachowując autorytet króla i jego uprawnienia w niezmienionej postaci. Wszystkie te zamierzenia okazały się jednak ponad siły Neckera, który według Staëla musiał walczyć przeciwko złej woli, słabości, niesłychanym pretensjom, nieznośnym intrygom i wyczerpaniu finansów, starając się jednocześnie zapobiec totalnej ruinie królestwa, gdzie wszystkie władze były sparaliżowane i gdzie nie było ani żadnej siły, ani dyscypliny wojskowej. W tak opłakanym stanie rzeczy niemożliwe okazało się opóźnienie lub też zatrzymanie impetycznego marszu nadciagającej rewolucji ${ }^{25}$.

${ }_{25}$ Por. ibidem. Ta sama depesza por. Corr, Staël-Holstein, s. 115-125 (tu błędna data - 15 zamiast 13 IX 1789 r.). Por. też A. Söderhjelm, op. cit., s. 213; Z. Anusik, op. cit., s. 233-236. 
W swojej następnej relacji Staël von Holstein w sposób zdecydowanie krytyczny odniósł się do tego, co działo się w Zgromadzeniu Narodowym. Wychowany w kraju o długiej tradycji parlamentarnej, nie potrafił zrozumieć tego, że Francuzi dopiero uczyli się podstawowych zasad uprawiania polityki. W depeszy z 17 września pisał więc do Gustawa III, że obserwacja poczynań Zgromadzenia potwierdza opinię, że Francuzi nie mają kwalifikacji do bycia naprawdę wolnym narodem. Traca bowiem niepotrzebnie czas, zamiast przywrócić porządek w kraju i dać królowi możliwość kierowania państwem. Obecnie zajmują się sprawą sukcesji tronu, zastanawiając się, czy w przypadku wygaśnięcia głównej linii Bourbonów nie należałoby wykluczyć od dziedziczenia linii hiszpańskiej i przyznać prawo do korony rodzinie Orleańskiej. Dyskusje na ten temat ambasador uznał za niesmaczne i niebezpieczne. W jego przekonaniu dwie frakcje walczyły wówczas o przewage w Zgromadzeniu. Jedna $z$ nich była partia, na czele której stał książę Ludwik Filip Orleański. Zdaniem Staëla, który nigdy nie lubił pierwszego księcia krwi i przychylał się do opinii, że to Anglia finansuje działania kierowanego przez niego ugrupowania, wysuwało ono zawsze skrajne i buntownicze pomysły. Jeszcze gorsza była jednak frakcja arystokratyczna, która zmierzać miała wprost do zdyskredytowania Zgromadzenia w oczach opinii publicznej. Ambasador wydawał się także dość poważnie zaniepokojony brakiem chleba w Paryżu. Wyciagał stąd wniosek o możliwości wybuchu kolejnych zamieszek w stolicy. Odnotował też pogłoskę, że władcy Prus, Sardynii i Hiszpanii mieli zaoferować królowi Francji pomoc zbrojną w celu uśmierzenia buntowniczych nastrojów. Przyznał jednak otwarcie, że ta nowina wymagać będzie dalszego potwierdzenia. Dnia 24 września Staël $z$ pewną satysfakcją mógł poinformować Gustawa III, że Zgromadzenie dostrzegło wreszcie konieczność wzmocnienia władzy wykonawczej, zgadzając się na przyznanie królowi veta zawieszającego na okres dwóch zgromadzeń prawodawczych. W tej samej depeszy pisał do króla, że Necker złożył w Zgromadzeniu sprawozdanie ze stanu finansów państwa. Wyraził przy tej okazji przekonanie, że jeśli plan Neckera zostanie przyjęty, to Francja być może wydobędzie się z kryzysu, w którym jest pogrążona. W trzy dni później Staël przekazał do Sztokholmu wiadomość, że Zgromadzenie przyjęło plan Neckera i nakazało wprowadzić go w życie. Ambasador był przekonany, że był to pierwszy krok na drodze do przywrócenia królowi jego władzy wykonawczej. Pozwolił sobie nawet na 
pewien optymizm, piszac, że jakkolwiek formuja się silne kabały przeciwników rządu tak wewnątrz kraju, jak i poza jego granicami, to przywrócenie porządku w finansach definitywnie oddali zagrażające Francji niebezpieczeństwa. W tym samym liście Staël wrócił także do sprawy pułków szwajcarskich, informując Gustawa III, że aczkolwiek nie zdecydowano jeszcze ostatecznie o losie Szwajcarów w służbie Francji, to nie powinno być większych trudności z przejęciem tych regimentów na żołd szwedzki ${ }^{26}$.

Tymczasem sytuacja we Francji uległa jednak dalszemu zaostrzeniu. Pod koniec września król ściągnął w okolice Wersalu kilka nowych oddziałów wojskowych, w tym pułk flandryjski. Wezwanie żołnierzy zostało odczytane przez część opinii publicznej jako prowokacja, tym bardziej że w Paryżu ponownie brakowało chleba, a emigracja arystokracji pozbawiła zajęcia wielu tamtejszych rzemieślników. Władze stolicy, wsparte przez liczna grupę deputowanych Zgromadzenia Narodowego, zażąały od ministra spraw wewnętrznych, hrabiego de Saint-Priest odwołania wojska. Doradcy króla zlekceważyli jednak nadciągające niebezpieczeństwo. W Wersalu nie doceniono ani rozmiarów kryzysu ekonomicznego, ani zniecierpliwienia opinii publicznej biernym oporem Ludwika XVI, wstrzymującego się $z$ zatwierdzeniem sierpniowych dekretów Konstytuanty. Sygnałem do wybuchu drugiej insurekcji paryskiej stał się drobny z pozoru incydent. Dnia 1 października 1789 r. oficerowie królewskiej gwardii przybocznej wydali w Wersalu bankiet powitalny dla oficerów pułku flandryjskiego. W chwili pojawienia się na sali rodziny królewskiej, rozgrzani winem biesiadnicy zaczęli wznosić entuzjastyczne okrzyki. Zrywali też i deptali trójkolorowe kokardy, zastępując je kokardami w barwach króla i królowej. Wieść o tych wydarzeniach, rozgłoszona w Paryżu 3 października, wywołała powszechne oburzenie. Prasa niemal natychmiast rozpoczęła antydworską kampanię, wzywając mieszkańców stolicy do marszu na Wersal ${ }^{27}$. Następnego dnia Staël von Holstein pisał w swojej depeszy o wielkiej agitacji, której zadaniem miało być wzburzenie nastrojów

${ }^{26}$ Por. E.M. Staël v. Holstein do Gustawa III, Paryż 17, 24 i 27 IX 1789, RA, Gallica vol. 472. Sprawa wynajęcia pułków szwajcarskich była bardzo istotna z punktu widzenia Gustawa III. Dnia 6 XI król zanotował bowiem na ostatniej z cytowanych tutaj depesz: „Zażądać od Staëla, żeby wysłał do Szwecji oddziały piechoty. Ma też rozejrzeć się za możliwością zaciagów w Niemczech. Niech zbiera też informacje o oficerach - ich talentach, charakterach, reputacji”. Por ibidem. Por też Corr. Staël-Holstein, s. 125-128.

${ }^{27}$ Por. A. Soboul, op. cit., s. 86-88; A. Mathiez, Rewolucja..., s. 76-78. 
społeczeństwa. Poddał też krytyce postępowanie Zgromadzenia Narodowego, niepotrafiacego zdobyć się na szybkie i jednoznaczne decyzje. Ambasador był także przekonany o tym, że Maria Antonina nie zaprzestała swoich intryg przeciwko Neckerowi i zmierza do usunięcia go $z$ ministerium. Opisując przebieg feralnego bankietu $z$ dnia 1 października, Staël sformułował opinię, że będzie on miał fatalne następstwa dla pary królewskiej. Niechętni znajdą bowiem doskonała okazję, by wysuwać najbardziej absurdalne oskarżenia przeciwko dworowi. Ganiąc niezrozumiała nieostrożność króla i królowej, ambasador pocieszał się jednak nadzieją, że uda się zapobiec marszowi mieszkańców stolicy na siedzibę Ludwika XVI ${ }^{28}$.

Nadzieja ta nie miała się jednak niestety spełnić. Już 8 października 1789 r. Erik Magnus Staël von Holstein pisał bowiem do Gustawa III, że następstwa nieszczęsnego obiadu wydanego przez gwardzistów króla okazały się i większe, i szybsze, niż mógł to przewidzieć. W swojej ostatniej depeszy donosił co prawda o wielkiej fermentacji w Paryżu, ale spodziewał się, że wzburzenie mieszkańców stolicy wkrótce zostanie uspokojone. Być może udałoby się to władzom nawet osiagnać, gdyby nie wielki brak chleba, który zmusił lud do potargania wszelkich wędzideł i wypowiedzenia zasad posłuszeństwa. Według relacji szwedzkiego ambasadora słynne wypadki 5 i 6 października 1789 r. miały następujacy przebieg. Zdesperowane i głodne kobiety $z$ hal targowych ruszyły najpierw do ratusza, oskarżając władze miejskie o sprowadzenie na Paryż klęski głodu. Tutaj podjęły decyzję, aby udać się do Wersalu i zażądać chleba od samego króla. Wdarły się następnie do miejskiego arsenału i zabrały stamtąd broń. Wyprowadziły także armaty. Gwardia narodowa nie potrafiła ich zatrzymać i wieczorem 5 października pierwsza grupa kobiet dotarła do Wersalu. Tymczasem La Fayette jeździł po całym Paryżu i zbierał oddziały w celu przywrócenia porządku. Okazało się jednak, że jego gwardziści również zamierzają wyruszyć do siedziby króla, żeby pomścić na gwardii przybocznej obrazę kokardy narodowej, jakiej dopuszczono się w czasie bankietu dla pułku flandryjskiego. La Fayette robił wszystko, aby ich powstrzymać. Prawdopodobnie nie doszłoby do wymarszu gwardzistów, gdyby nie podżegania ze strony paryskich kobiet, które zarzuciły żołnierzom tchórzostwo. W tej sytuacji wszystkie wysiłki La Fayette’a okazać się miały bezowocne. Powiedziano mu, że albo stanie na czele swoich

${ }^{28}$ Por. E.M. Staël v. Holstein do Gustawa III, Paryż 4 X 1789, RA, Gallica vol. 472; Corr. Staël-Holstein, s. 128-129. Por. też Z. Anu sik, op. cit., s. 238. 
oddziałów i pomaszeruje $z$ nimi na Wersal, albo zostanie na miejscu powieszony. O piątej po południu La Fayette $z$ gwardzistami wyruszył więc w kierunku Wersalu. Podążyło za nim 12 tys. kobiet, prowadzacych ze sobą 24 działa. Mer Paryża - Jean Sylvain Bailly musiał się ukryć tego ranka, gdyż zdesperowane niewiasty chciały go powiesić, oskarżając go o spowodowanie drożyzny zboża. W czasie, kiedy paryskie kobiety maszerowały do siedziby Ludwika XVI, jeden $z$ oficerów, który wiedział, że monarcha poluje w okolicach Meudon, pojechał do niego i poinformował go o zaszłych wypadkach. Po otrzymaniu tej wiadomości król natychmiast wrócił do Wersalu. Bezzwłocznie podjęto też niezbędne przygotowania do obrony. W pobliże pałacu sprowadzono 1000 uzbrojonych mieszczan wersalskich. Gwardia królewska również stanęła pod bronią. Zamknięto także wszystkie bramy i ze spokojem oczekiwano nadejścia kobiet, do których tymczasem przyłączyło się wielu uzbrojonych mężczyzn $z$ ludu ${ }^{29}$.

Zupełnie niespodziewanie doszło jednak, $z$ jakiejś błahej przyczyny, do scysji między mieszczanami wersalskimi a gwardzistami króla. Utarczki słowne przekształciły się w bójkę, która stała się sygnałem do odłączenia się oddziału mieszczan od gwardii królewskiej. To zaalarmowało dwór, gdyż wskutek odstępstwa wersalczyków niebezpieczeństwo wyraźnie wzrosło. W tej sytuacji Rada Królewska zdecydowała się użyć łagodnych środków. Tymczasem nadciagnał tłum kobiet i 400 spośród nich wtargnęło do sali posiedzeń Zgromadzenia Narodowego, żądając od deputowanych chleba i obniżenia cen artykułów spożywczych. Przerażone Zgromadzenie wysłało do króla deputację, prosząc go, aby wysłuchał żądań ludu. Ludwik XVI zgodził się udzielić audiencji sześciu niewiastom, które miały mu przedstawić wszystkie skargi. Wiele innych kobiet również usiłowało wejść przy tej okazji do pałacu, ale zostały one brutalnie powstrzymane przez gwardzistów królewskich. To dodatkowo wzburzyło tłum przeciwko żołnierzom tej formacji. Odpowiedź udzielona przez króla delegacji kobiet rozładowała jednak napięcie i zadowolony tłum ruszył $z$ powrotem do Paryża. Na dworze uznano więc, że niebezpieczeństwo minęło i nakazano oddziałom gwardii wycofać się do koszar. W tej samej chwili nadeszły jednak nowe, alarmujące nowiny. Doniesiono bowiem, że ogromne masy ludu wylewają się ze wszystkich bram Paryża i kierują się w stronę Wersalu.

${ }^{29}$ Por. E.M. Staël v. Holstein do Gustawa III, Paryż 8 X 1789, RA, Gallica vol. 472. 
La Fayette zupełnie stracił głowę i nie uczynił niczego, co mogłoby zapobiec nadchodzącym wypadkom. W otoczeniu króla też nie bardzo wiedziano, co należy robić. Jedni uważali, że monarcha powinien natychmiast wyjechać $z$ Wersalu i schronić się na prowincji. Inni $z$ kolei twierdzili, że nic nie byłoby bardziej zgubne, jak oddalenie się władcy $z$ jego dotychczasowej siedziby. Trwały bezowocne obrady Rady Królewskiej, a wszystkie nowe pomysły były na ogół sprzeczne $z$ poprzednimi. Nie wiedziano też dokładnie, co tak naprawdę dzieje się w Paryżu. Ministrowie wysyłali kurierów, ale żaden $z$ nich nie wracał. Dopiero o 9 wieczorem przyjechał adiutant La Fayette'a, anonsujac jego przyjazd. To zupełnie zmieniło nastroje. Konsternacja ustąiła miejsca niepohamowanej chęci zemsty ze strony dworzan za doznane tego dnia upokorzenia. Król długo się namyślał, co powinien zrobić w tej sytuacji. Rozważał nawet możliwość opuszczenia Wersalu, ale w końcu zgodził się przyjąć La Fayette’a. Na wszelki wypadek przygotowano jednak sześć powozów, które miały być w każdej chwili gotowe do wyjazdu. Lud nie wypuścił ich jednak poza obręb pałacu ${ }^{30}$.

Staël von Holstein uważał, że pomysł wyjazdu rodziny królewskiej był najgorszy $z$ możliwych, gdyż narażał na okropne niebezpieczeństwa wszystkie dystyngowane osoby $z$ jej otoczenia, które $z$ pewnościa stałyby się pierwszymi ofiarami wściekłości ludu, gdyby ten dowiedział się o ucieczce króla. Po tej dygresji ambasador wrócił jednak do przerwanego toku opowiadania. Według niego, La Fayette zjawił się w Wersalu dopiero o 11 wieczorem. Zaraz też został wprowadzony do króla. Obiecał władcy, że jego żołnierze zachowaja dyscyplinę i utrzymaja porządek, jeśli tylko monarcha zgodzi się powierzyć im straż jego osoby. Ludwik XVI zgodził się na to rozwiązanie i La Fayette wrócił do swoich oddziałów. W nocy jednak milicja $z$ Wersalu przekonała swoich kolegów $z$ Paryża do pomysłu wspólnego wystapienia przeciwko gwardzistom króla i około 3 nad ranem rozpoczęto prześladowanie tych biedaków. Kilku zabito, a wielu raniono. Około 7 rano gwardziści królowej przyszli do jej sypialni, ostrzegając ja, że jest ich zbyt mało, aby mogli skutecznie jej bronić. Prosili więc Marię Antoninę, by natychmiast pomyślała o swoim ratunku. Królowa wstała więc $z$ łóżka i udała się do pokoju męża. Również wielu pokonanych żołnierzy z gwardii przybocznej szukało schronienia w jego apartamentach. Widziano

30 Por. ibidem. 
wiele krwi na galerii i na schodach. W końcu nieszczęśliwi gwardziści króla poddali się i zostali wzięci pod opiekę przez paryską gwardię narodową. Założyli na głowy czapki stołecznej milicji i tak przystrojeni pokazali się ludowi. To stało się hasłem do zaprzestania krwawych prześladowań. Następnie król został zmuszony do wyrażenia zgody na przeniesienie się z rodziną i dworem do Paryża. Stany Generalne [Konstytuanta] zebrały się natychmiast na nadzwyczajnym posiedzeniu, na którym monarcha notyfikował im swój zamiar udania się do Paryża. Na wieść o tym, również Zgromadzenie podjęło uchwałę, że będzie towarzyszyło władcy w jego przenosinach. To był zadziwiający i zasmucający zarazem spektakl, gdy widziało się króla, królową, Monsieur, książąt, dworzan i oficerów przyozdobionych narodowymi kokardami. Zaopatrzeni w paszporty bezpieczeństwa, wydane dla całego dworu przez La Fayette’a, około 1 po południu Ich Wysokości wyruszyły w drogę do Paryża. Bailly, który opuścił tymczasem swoje schronienie, podejmował ich w ratuszu. Tak skończył się ten przerażający i poniżający dla rodziny królewskiej dzień. Swoją relację zakończył Staël stwierdzeniem, że to, co przeraża go najbardziej, to nienawiść między arystokratami a partią ludowa, która realizuje swoje partykularne interesy w imię miłości ojczyzny i nazwiska Orleanów, po to tylko, żeby przejąc całą władzę i wynieść swojego przywódcę [czyli księcia Orleańskiego - przyp. Z.A.] na pierwsze miejsce w kraju. Zdaniem ambasadora, obie zwalczające się partie, aczkolwiek $z$ różnych powodów, chciały przyjazdu króla do Paryża. Obie przyłożyły też ręki do realizacji tego celu. Miały być także zgodne w jeszcze jednym punkcie. Wolałyby bowiem raczej rozpętać wojnę domowa, niż pozwolić na osiągnięcie przewagi przez konkurencyjne stronnictwo. Zacięta rywalizacja obu frakcji, a także fakt, że prowincja mogła się poczuć urażona tak znaczącym zwiększeniem się wpływu stolicy zarówno na króla, jak i na Zgromadzenie Narodowe, nie wróżyły dobrze na przyszłość. Szwedzki dyplomata określił ją mianem złowrogiej, przewidując nadejście kolejnych jeszcze wstrząsów i zaburzeń ${ }^{31}$.

${ }^{31}$ Por. ibidem. Ta sama depesza por. Corr. Staël-Holstein, s. 129-135. Szerzej na temat opisywanych przez Staëla wypadków por. M. Mign et, Historya rewolucyi francuskiej od roku 1789 do 1814, Warszawa 1890, s. 72-77; A. S o b o u1, op. cit., s. 88-89; A. Mathiez, Rewolucja..., s. 78-80; N. Åkes on, op. cit., s. 19-20; L. Villat, op. cit., s. 53-56; J. Baszkiewicz, op. cit., s. 222-223; Z. Anusik, op. cit., s. 238-241. Warto też zauważyć, że ustalenia tych badaczy różnia się w pewnych szczegółach od relacji szwedzkiego dyplomaty. 
Zdaniem Alberta Mathieza zmiana miejsca pobytu króla miała większe znaczenie niż wzięcie Bastylii. Ludwik XVI i Zgromadzenie Narodowe znaleźli się odtąd pod kontrolą ludu paryskiego i La Fayette'a, komendanta gwardii narodowej. Wypadki październikowe oznaczały też porażkę monarchistów, którzy od początku rewolucji zachęcali króla do oporu przeciwko wprowadzanym reformom. Ich przywódca - Jean Joseph Mounier, porzucił funkcję przewodniczącego Zgromadzenia i wyjechał do Delfinatu, by wzniecić tam powstanie. Przykład Mouniera naśladowali jego polityczni przyjaciele. Ponieważ jednak nigdzie nie udało im się wywołać antyrządowych zaburzeń, wkrótce potem przywódcy monarchistów zdecydowali się na opuszczenie Francji ${ }^{32}$. Nieco inaczej widział tę sprawę Staël von Holstein, który 11 października 1789 r. pisał w swojej kolejnej depeszy, że lekkomyślność narodu francuskiego, jego brak charakteru i nade wszystko jego skrajna gwałtowność i niemoralność czynia możliwymi największe okrucieństwa i absurdy. Według Staëla okrucieństwem i absurdem był bowiem fakt, że przywódcy monarchistów - Jean Joseph Mounier, Pierre Victor Malouet, hrabia de Vivien i 15 innych deputowanych, zostali zmuszeni do wyjazdu z Paryża przez partie orleańską. Ambasador wydawał się przekonany o tym, że każdy, kto przeciwstawia się woli księcia Orleańskiego, wystawia się na wielkie niebezpieczeństwo. Zważywszy zaś na fakt, że książę cieszy się wielkim poparciem ze strony niższych warstw społecznych, rząd nie może sobie pozwolić na otwarte wystapienie przeciwko niemu. Uprzedzając wyniki śledztwa przeciwko sprawcom zaburzeń z 5 i 6 października, Staël pozwolił też sobie na autorytatywne stwierdzenie, że to panowie Alexandre de Lameth, Joseph Antoine Barnave i Adrien Duport byli tymi, którzy wzniecili powstanie w Paryżu i dopuścili się gwałtu na osobie króla i Zgromadzenia Narodowego. Zdaniem ambasadora wszystko wskazywało wówczas na to, że wkrótce dojdzie we Francji do wybuchu wojny domowej. Jego przerażenie budziły też okrucieństwa, których lud dopuszczał się na tych, których uważał za swoich wrogów. W końcowym fragmencie cytowanej depeszy pisał bowiem: „Nie da się też opisać barbarzyństwa, z jakim Francuzi traktuja nieszczęsne ofiary, które zginęły w tej rewolucji. Wielu gwardzistów króla zostało zamordowanych w chwili, gdy złożyli już broń i gwardia narodowa próbowała ich ocalić. Odcięto głowy dwóch $z$ nich i przyniesiono

${ }^{32}$ Por. A. Mathiez, Rewolucja..., s. 80-81. Bardziej szczegółowe omówienie zasygnalizowanego tutaj problemu por. J. Eg ret, La révolution des notables: Mounier et les monarchiens. 1789, Paris 1950. 
je $z$ triumfem do Paryża. W tej chwili panuje tu obawa, że najemni podpalacze moga wzniecić pożary w Paryżu. Wiele domów w tym mieście zostało oznaczonych. Mój jest w tej liczbie. Mam jednak nadzieję, że Opatrzności spodoba się uchronić nas przed tym nieszczęściem”.

W następnych depeszach Staël von Holstein informował Gustawa III o perypetiach księcia Orleańskiego. Według niego La Fayette zmusił księcia do wyjazdu z Paryża, grożąc mu ujawnieniem wszystkich jego intryg. Przestraszony książę wyjechał do Londynu $z$ fikcyjna misją rządowa, którą zlecono mu tylko po to, aby ułatwić mu honorowy odwrót. Mieszkańcy Boulogne zatrzymali jednak księcia Orleańskiego, nie zezwalając na jego wyjazd do Anglii, po czym czworo urzędników tamtejszego magistratu przyjechało do stolicy z zapytaniem, czy można go wypuścić. Otrzymali odpowiedź, że nie należy czynić żadnych przeszkód w jego wyjeździe. W pisanej w dniu 18 października relacji ambasador pozwolił sobie wreszcie na pewną nutkę optymizmu, stwierdzając, że przeniesienie się króla do Paryża, początkowo uważane za wielkie nieszczęście, może jednak przyczynić się do odzyskania przez niego utraconego na początku rewolucji zaufania ludu ${ }^{33}$.

Dnia 22 października 1789 r. Erik Magnus Staël von Holstein, wykonując wcześniejsze rozkazy Gustawa III, sporządził obszerny raport o aktualnej sytuacji państwa francuskiego. Ze względu na wage zawartych tam sformułowań zasługuje on $z$ pewnościa na to, aby przytoczyć jego najważniejsze fragmenty. Swoją relację rozpoczą ambasador od przypomnienia kilku istotnych wydarzeń z początków rewolucji, pominiętych w jego poprzednich depeszach. Zdecydował się na ten zabieg, gdyż uznał, że znajomość tych faktów pomoże szwedzkiemu królowi w lepszym zrozumieniu tego wszystkiego, co stało się we Francji. W pierwszym rzędzie odniósł się do wypadków z 14 lipca. Według niego, wieść o zdymisjonowaniu Neckera wywołała w stolicy powszechną konsternację. Na znak żałoby lud zażądał zamknięcia wszystkich paryskich teatrów, co natychmiast zostało wykonane. Konsternacja zmieniła się we wściekłość, kiedy książę

${ }^{33}$ Por. E.M. Staël v. Holstein do Gustawa III, Paryż 11 X 1789, apostille nr 2 oraz 15 i 18 X 1789, RA, Gallica vol. 472; Corr. Staël-Holstein, s. 135-137. Por. też A. Söderhjelm, op. cit., s. 210; Z. Anusik, op. cit., s. 242-243. W kwestii kulis usunięcia się z Paryża księcia Orleanu (Staël okazał się znakomicie poinformowany w tym względzie) por. A. Mathiez, Rewolucja..., s. 81-82; Ludwik Filip, Pamiętniki z czasów Wielkiej Rewolucji, oprac. W. Dłuski, wstęp J. Baszkiewicz, Warszawa 1988, s. 86-90. 
de Lamballe [w rzeczywistości pułkiem tym dowodził książę de Lambesc - przyp. Z.A.] wykonał szarżę na lud ze swoim regimentem Royal Allemand i ścigał go aż do pałacu Tuileries. To doprowadziło do podjęcia natychmiastowych zbrojeń przez rozgoryczony lud. Paryż $z$ pewnościa zostałby spalony i splądrowany w nocy $z$ poniedziałku na wtorek, gdyby w poniedziałek nie doszło do uzbrojenia paryskiej gwardii narodowej, która zapobiegła niepokojom. W Wersalu nic nie wiedziano o tym, co dzieje się w stolicy. Królowa i Polignacowie zabawiali się koncertem zorganizowanym w oranżerii pałacu wersalskiego w tym samym czasie, kiedy w Paryżu lud zdobywał Bastylię. Wicehrabia Louis Marie de Noailles był pierwszym, który przyniósł królowi wieści o wzięciu Bastylii, zamordowaniu panów de Launaya i Flessellesa oraz o straszliwym nieładzie panującym w stolicy. Pan Berthier, intendent Paryża, w obecności Noaillesa zdementował jednak jego nowiny, mówiąc królowi, że w mieście panuje całkowity spokój. Według ambasadora był to dowód całkowitej niekompetencji ludzi odpowiedzialnych za bezpieczeństwo i porządek w stolicy Francji. Komentując wypadki z 17 lipca, Staël nie ukrywał swojego potępienia dla lekkomyślności doradców Ludwika XVI. Pisał bowiem, że kiedy w piątek monarcha pojechał do Paryża, na ulicach miasta znajdowało się 200 tys. uzbrojonych ludzi. Gdy otoczona przez olbrzymi tłum kareta królewska $z$ najwyższym trudem posuwała się $\mathrm{w}$ kierunku ratusza, król był wystawiony na wielkie niebezpieczeństwo. W każdej chwili mógł bowiem zostać postrzelony przez jakiegoś desperata $z$ uzbrojonego po zęby tłumu. Nie obeszło się też bez ofiar. Ranny został porucznik gwardii jadący obok karety króla, a jakaś kobieta została nawet zabita. Zdaniem Staëla można było uznać za prawdziwy cud, że władca cały i zdrowy wrócił do Wersalu ${ }^{34}$.

Charakteryzując sytuacje panująca w Zgromadzeniu Narodowym [Konstytuancie], Staël von Holstein stwierdził, że jest ono podzielone na cztery główne partie. Pierwsza $z$ nich to stara partia arystokratyczna. Członkowie tego ugrupowania postawili sobie za cel utrzymanie za wszelką cenę ancien régime'u. Ambasador nie miał wielkiego sentymentu dla tego ugrupowania. Pisał bowiem, że jego bezużyteczne zabiegi prowadza tylko do wywołania wściekłości jego wrogów, wzmagają niezadowolenie ludu i sa pretekstem do nowych rewolucji, które prowadzą do coraz większego poniżenia szlachty i duchowieństwa. Jego zdaniem partia arystokratyczna była

${ }^{34}$ Por. E.M. Staël v. Holstein do Gustawa III, Paryż 22 X 1789, RA, Gallica vol. 472. 
najbardziej pogardzana i sama też pogardzała wszystkimi. Atutem tej partii było to, że była oddana tronowi i sympatyzowało $z$ nia całe otoczenie królowej wraz $z$ nią samą. Naturalnym przywódca tej partii był hrabia d’Artois. W opinii Staëla to właśnie partia arystokratyczna w największym stopniu przyczyniła się do pogłębienia obecnych trudności. To właśnie arystokraci byli bowiem odpowiedzialni za nieszczęsny obiad wydany przez gwardzistów króla. To oni doprowadzili do wybuchu rebelii w Paryżu i za jej skutki nie moga winić nikogo oprócz siebie. Ambasador był przekonany, że partia ta skazana jest na klęskę w konfrontacji z jej przeciwnikami. Czym bowiem jest 100 tys. szlachty wobec 24 mln ludu, czym sa oficerowie bez żołnierzy? Interesów partii arystokratycznej bronili w Zgromadzeniu ludzie, którzy w opinii Staëla von Holsteina swoim postępowaniem przyczynili się do zohydzenia w oczach opinii publicznej nazwy arystokracji i doprowadzili do rozpowszechnienia pogłoski o istnieniu arystokratycznego spisku skierowanego przeciwko ludowi. Byli nimi w pierwszym rzędzie Jean Jacques d'Eprémésnil, „sławny parlamentarzysta, najgorętszy zwolennik zasady działania zgodnie $z$ obowiazującym prawem”, oraz ksiądz Jean Siffrein Maury, „człowiek godny pogardy”. Zdaniem ambasadora obaj byli na tyle zręczni i wymowni, że udało im się uzyskać pewien wpływ na deputowanych ${ }^{35}$.

W dalszej części swojego raportu Erik Magnus Staël von Holstein pisał w sposób następujący: „Wspomnieć też trzeba o ugrupowaniu, w skład którego wchodza wszyscy dworzanie, wszyscy biskupi i wszyscy, którzy stracili na ustanowionym właśnie nowym porzadku rzeczy. Chcieliby oni powrotu do arbitralnych rząów i $z$ tego powodu sa pogardzani przez wszystkich uczciwych ludzi. $\mathrm{Na}$ obrzeżach tej partii działa jedyny uczciwy, jedyny dobrze usposobiony, zniesławiany jednak przez zaciekłych demokratów, którzy chcieliby utożsamić go $z$ partią arystokratyczną, człowiek - pan Mounier. To on pierwszy zaczał rewolucję w Delfinacie. Bieg wydarzeń nie zmienił jego dawnych zapatrywań i dziś należy on do bardziej umiarkowanych. Mounier jest równie daleki od arystokracji, jak od demokracji. Jest on przekonany o konieczności utrzymania monarchii i potrzebie dania jej władzy wykonawczej w celu utrzymania porządku. Jest wielbicielem konstytucji angielskiej, zwolennikiem dwóch izb w zgromadzeniu prawodawczym i veta

35 Por. ibidem. 
absolutnego, a więc porządku dalekiego od tego, który jest właśnie ustanawiany. $Z$ panem Mounier związany jest markiz [Trophime Gérard - przyp. Z.A.] de Lally-Tolendal, człowiek elokwentny i uczciwy. Hrabia [Stanislas Marie - przyp. Z.A.] de Clermont-Tonnere, zdobył sławę dzięki pełnemu godności sposobowi, w jaki przewodzi obradom Zgromadzenia i dzięki łatwości, z jaka przemawia. Jego zdanie ma wpływ na wszystkich uczciwych ludzi w Zgromadzeniu Narodowym i na ministrów króla, którzy w walce $z$ arystokratami gotowi byliby widzieć w nim swojego sprzymierzeńca. Zarówno Clermont-Tonnere, jak i ministrowie króla są wrogo usposobieni wobec demokratów, których intrygi zmierzają do pograżenia kraju $\mathrm{w}$ anarchii. Szlachetne cele stawiane sobie przez partię kierowana przez Mouniera moga jednak okazać się wielce szkodliwe ze względu na miłość własna jej przywódcy. Pan Mounier gotów jest bowiem pogrążý królestwo w ogniu wojny $z$ powodu dwóch izb i veta absolutnego. I jakie by nie były jego racje polityczne, sa to pomysły niepraktyczne, a strach przed arystokracja jest tak wielki, że nie ma mowy o tym, by udało się utworzyć druga izbę, która $z$ pewnościa stałaby się $z$ czasem arystokratycznym azylem".

Trudno oprzeć się wrażeniu, że szwedzki dyplomata wyraźnie sympatyzował $z$ programem politycznym ugrupowania kierowanego przez Mouniera. Nie akceptował jednak proponowanych przez niego metod. W dalszej części swojego raportu pisał bowiem, że w Zgromadzeniu Narodowym tworzonych jest wiele kabał i spisków, które rozbijają je wewnętrznie i uniemożliwiają szybką i skuteczną pracę. Ugrupowanie Mouniera zaczęło też rozgłaszać opinię, że Konstytuanta nie może podejmować suwerennych uchwał w Paryżu i w związku $z$ tym powinna przenieść swoje obrady do Delfinatu. Staël przewidywał jednak, że gdyby do tego doszło, byłby to sygnał do rozpoczęcia wojny domowej. Nie pochwalał również pomysłu Mouniera dotyczącego zwołania stanów prowincjonalnych Delfinatu w celu przeciwstawienia ich Zgromadzeniu Narodowemu. Uważał bowiem, że przykład ten mógłby być naśladowany przez inne prowincje, co prowadziłoby w prostej linii do destabilizacji państwa. Poświęciwszy tak wiele uwagi ugrupowaniu, $z$ którym łączyły go wyraźne sympatie polityczne, Staël von Holstein nie omieszkał zaznaczyć, że zarówno Mounier, jak i Lally-Tolendal wyjechali już z Paryża ${ }^{36}$.

${ }^{36}$ Por. ibidem. 
Nieobecny w stolicy był także przywódca „konspiracji raczej niż partii”, książę Ludwik Filip Orleański, o którego wyjeździe do Londynu ambasador donosił w swoich poprzednich depeszach. Zdaniem Staëla, który od dawna pogardzał tym kuzynem królewskim, książę Orleanu należał do największych wrogów Ludwika XVI. Brakowało mu jednak odwagi, co udowodnił w czasie lipcowych i październikowych wydarzeń paryskich. Ambasador był przekonany, że gdyby książę wykazał wówczas odwagę i zdecydowanie, mógłby zostać panem królestwa. Trzymając się na uboczu wydarzeń, stracił jednak swoją szansę. Według Staëla partia orleańska składała się $z$ hrabiego Louisa René de La Touche-Tréville, kanclerza księcia Orleańskiego, Armanda Louisa księcia de Biron - jego przyjaciela i markiza Charlesa Alexisa de Sillery, kapitana jego gwardii. Krążyły także pogłoski, że na usługach księcia pozostawał, przebywający od dłuższego już czasu w Londynie, były minister finansów, Charles Alexandre de Calonne. Ambasador przychylał się także do uznania za prawdę plotki, że działalność kabały orleańskiej finansowana była przez dwór angielski. Sumy, które jej zwolennicy rozdzielali wśród ludności, miały bowiem przekraczać możliwości finansowe księcia. W chwili, kiedy Staël pisał swój raport, do Paryża dotarła też wiadomość, że książę Orleański rozpoczą starania o uzyskanie nominacji na stanowisko ambasadora Francji na dworze św. Jakuba. Charakteryzujac postaci wielce wpływowych w Zgromadzeniu hrabiego Honoré Gabriela de Mirabeau i Charlesa Maurice'a de Talleyranda, biskupa Autun, Staël von Holstein zanotował w swoim raporcie: „Sławny hrabia de Mirabeau, który sprzedaje się wszystkim, ma różnorakie talenty, rozum i elokwencję tak niepospolitej natury, że potrafi podporządkować sobie nawet tych, którzy nim pogardzają. Ten człowiek gardzi wszelkimi pozorami, nie tyle $z$ powodu czystości swoich intencji, ale dlatego, że jest pewien, że zawsze potrafi dopasować stosowane przez siebie środki do zamierzonego celu".

Zdaniem ambasadora Mirabeau koniecznie chciałby zostać ministrem. Na przeszkodzie w realizacji tego celu stała jednak niechęć Neckera, który nigdy nie zgodziłby się na pozostanie w ministerium razem $z$ nim. Zdając sobie sprawę $z$ wpływów Mirabeau w Zgromadzeniu, rząd usiłował go przekupić. Nie było to jednak zadanie łatwe, gdyż w opinii szwedzkiego dyplomaty zabiegi wokół osoby Mirabeau trzeba było ponawiać nie tylko każdego dnia, lecz niemal każdej godziny. „Jest to bowiem umysł ruchliwy i zmienny. 
Nie dochowuje wierności nawet własnym pomysłom i nikt nie potrafi przewidzieć tego, co powie lub też co zrobi w najbliższym czasie".

Według Staëla von Holsteina jedynym człowiekiem, którego Mirabeau cenił w Zgromadzeniu, był ten, któremu niegdyś wyrzadził on wielką krzywdę, ujawniając sprawę jego tajnej korespondencji $z$ dworem berlińskim. Tajnym korespondentem dworu pruskiego był nie kto inny, jak Charles Maurice de Talleyrand, zwany niegdyśs księdzem de Périgord, wówczas biskup Autun. W czasie, kiedy Staël sporządzał swój raport, dawni wrogowie byli już podobno w doskonałej komitywie. O Talleyrandzie ambasador pisał: „Na dobro biskupa Autun trzeba zapisać, że nie brał dotąd udziału w żadnej intrydze w Zgromadzeniu. Biskup jest człowiekiem rozumnym, nadającym się do polityki ze względu na celność i pewność swoich przekonań. Jego ambicje sa jednak daleko większe niż jego fortuna. Również on ma ambicje zostania ministrem. Ma jednak dość rozumu, by odłożyć chwilę swojego wejścia do ministerium, gdzie Necker jest trudny do zastapienia i gdzie nawarstwiło się wiele palących, a trudnych do rozwiązania problemów. Nie stanowi on obecnie poważniejszego zagrożenia dla spokoju publicznego".

Uwagę ambasadora zwrócił jednak fakt, że w Zgromadzeniu biskup Autun współdziałał $z$ księdzem Emmanuelem Josephem Sieyèsem, „najbardziej dumnym i najbardziej wzniosłym logikiem systematycznym”, którego „z pewnością lepiej się czyta, niż słucha”. W opinii szwedzkiego dyplomaty Sieyès niezdolny do intryg, odznaczył się wielką odwaga, $z$ jaka okazywał Zgromadzeniu swoja pogardę dla jego bezprzedmiotowych deliberacji ${ }^{37}$.

Zdecydowanie niechętny był stosunek Staëla von Holsteina do ugrupowania, które uważano za demokratyczne. Pisał o nim bowiem w następujący sposób: „Oddzielnie od biskupa Autun, oddzielnie od Sieyèsa i Mirabeau, oddzielnie od wszystkich uczciwych i utalentowanych ludzi rozwija się kabała, która sprzymierzyła się ze spiskiem księcia Orleańskiego. Szermując demagogicznymi hasłami wolności dla ludu i wysuwając żądania uchwalenia demokratycznej konstytucji, partia ta używa wszystkich dostępnych jej środków, aby podjudzać lud i wzniecać rozruchy tak w Pary$\dot{z} u$, jak i na prowincji. Wszystko to ma doprowadzić do obalenia

37 Por. ibidem. 
rządu, w którym planuje się zatrzymać tylko Neckera, ze względu na jego kredyt u bankierów i popularność wśród ludu. Ludzie ci byliby jednak gotowi poświęcić również jego, gdyby tylko przestał im być użyteczny. To oni dopuszczaja się obrzydliwych oskarżeń pod adresem rządu, rozpuszczaja najbardziej niegodziwe plotki i uciekają się do różnych sztuczek, aby spowodować brak chleba na rynku. Na czele tej partii, która w Zgromadzeniu wspierają Bretończycy i wszystkie niespokojne duchy, stoi pan [Adrien - przyp. Z.A.] Duport. Ceniony zwłaszcza dlatego, że nigdy nie podzielał przesąów swojej korporacji. Jego charakter jest jednak fałszywy, a sposób wysławiania trudny. Entuzjastyczny frondysta, mający fałszywe rozeznanie i ambicję bez środków, mówi ciągle o wolności, a mierzy w ministerstwo. Pan [Joseph Antoine - przyp. Z.A.] Barnave, deputowany stanu trzeciego, naśladuje jego przykład i podziela, o ile to możliwe, wszystkie jego poglądy. Gra jednak rolę drugorzędna, pozostajac w cieniu Duporta. Będąc drugim w czynieniu dobra, chciałby być pierwszym w czynieniu zła. Jest to człowiek rozumny, utalentowany i z charakterem, ale bez środków. Stał się wstrętny dla wielu uczciwych ludzi ze względu na surowość, jaką okazał w czasie masakr w Paryżu. Kawaler Alexandre de Lameth to młody człowiek, całkowicie zrujnowany, ambitny, o charakterze nieposkromionym, który nie ujawnił jednak dotąd ani żadnego talentu, ani też nadzwyczajnej mądrości. Nie jest lubiany ze względu na swoja mściwość i wyniosłość. Partia, do której należą ci trzej panowie, przez długi czas nazywana była partia La Fayette'a. Ostatnio jednak La Fayette odsunął się nieco od wspomnianej trójki. La Fayette to bardzo zdolny człowiek, ale nie odgrywa roli, którą chciałby odgrywać. Na swoje nieszczęście ma ambicje większe niż możliwości ich zaspokojenia. Ci, którzy go dobrze znaja, mówią, że tylko on jest w stanie uratować Francję, a przynajmniej ocalić ja przed totalna ruiną, mając w swoim ręku tę resztkę siły, jaka pozostała w tym kraju. Los królestwa zależy bowiem od spokoju w Paryżu. Ten $z$ kolei jest w rękach La Fayette'a. Mówi się, że chciałby on dać królowi sposobność wyjazdu z Paryża, żeby przekonać prowincję, że król nie jest więźniem stolicy. Ci, którzy znają skłonność markiza do rządu demokratycznego, uważają, że łączą go jakieś związki z buntownikami, zawsze skłonnymi do wywołania kolejnych niepokojów". 
Staël von Holstein nie dawał jednak wiary tym oskarżeniom i był przekonany o tym, że La Fayette, zdecydowany zwolennik przywrócenia zachwianego porządku, rzeczywiście mógłby odegrać we Francji rolę męża opatrznościowego ${ }^{38}$.

Niezbyt dobre mniemanie miał ambasador o francuskim ministerium. Jego zdaniem spośród wszystkich ministrów jedynie Necker wyróżniał się licznymi talentami, rozumem i wykształceniem. Ulubieńcem deputowanych miał być natomiast strażnik pieczęci, arcybiskup Bordeaux [Jérôme Marie Champion de Cicé - przyp. Z.A.], który w czerwcu doprowadził do połączenia się stanów, zachęcając swoim przykładem większość duchowieństwa do przyłączenia się do reprezentacji stanu trzeciego. W końcowych fragmentach swojego raportu Staël von Holstein napisał: „Pozycja króla jest taka jak zawsze. Jest lubiany, zdobył sobie nawet pewna popularność, ale ten naród jest tak niekonsekwentny, że nie można $z$ tego wyciagać żadnych pozytywnych wniosków. To z miłości do króla zmuszono go przecież do przyjazdu do Paryża. Po to, żeby mu służyć, zmasakrowano jego gwardzistów".

Zdaniem Staëla również „królowa zyskała nieco w oczach opinii publicznej dzięki heroicznej odwadze, jaką okazała. Lekcja, którą dostała, była jednak tak surowa, że panuje powszechne przekonanie, że jest ona zdecydowana nie mieszać się więcej do polityki”.

Co do Monsieur, to według ambasadora, przestał on odgrywać jakąkolwiek rolę w polityce. Ze względu na swoja nicość zdołał też uniknąć zarówno miłości, jak i nienawiści ze strony ludu. Pisząc swój raport, Staël nic nie wiedział o książętach krwi, którzy po 17 lipca wyjechali $z$ kraju. Nie przypuszczał, aby zachowali oni jakieś kontakty ze swoimi zwolennikami we Francji. W jego głębokim przekonaniu emigranci nie stanowili w owym czasie żadnego zagrożenia dla spokoju publicznego, nie wzbudzając jakiegokolwiek zainteresowania szerszej publiczności. Staël przypuszczał, że książęta mogliby wrócić do kraju jedynie wówczas, gdyby doszło do wybuchu wojny domowej i któraś $z$ walczacych stron zdecydowałaby się wezwać ich $z$ powrotem ${ }^{39}$.

38 Por. ibidem.

39 Por. ibidem. Ta sama depesza por. Corr. Staël-Holstein, s. 137-146; jej streszczenie por. A. Söderhjelm, op. cit., s. 214; N. Åkeson, op. cit., s. 12-16; A. Geffroy, op. cit., t. II, s. 93 i n.; Z. Anusik, op. cit., s. 243-249. Szersze omówienie opisywanych przez Staëla problemów z charakterystyka głównych stronnictw politycznych Konstytuanty oraz ich przywódców por. M. Żywczyński, 
Przedstawiony przez Staëla obraz francuskiej sceny politycznej nie odbiega w zasadzie od tego, co piszą na ten temat współcześni historycy. Nie można również niczego zarzucić jego poprzednim doniesieniom. Ambasador był bowiem na ogół rzetelnie poinformowany o rozgrywających się we Francji wypadkach i jeśli nawet mylił się w jakichś drobnych szczegółach, to potrafił znakomicie przeniknąć istotę i oddać atmosferę przemian, których był naocznym swiadkiem. Co w tym wszystkim wydaje się jednak najbardziej interesujące, to fakt, że Gustaw III, otrzymujacy tak dokładne i wnikliwe raporty $z$ Paryża, nie był $z$ nich wcale zadowolony. To prawda, $\dot{z}$ e swoje negatywne odczucia zapisał jeszcze przed otrzymaniem relacji z 22 października, niemniej jednak 17 listopada 1789 r. król sporządził notatkę, zgodnie $z$ która Ulric Gustaf Franc miał nakazać sekretarzowi paryskiej legacji - Aronowi Isacowi Silfversparremu, sporządzenie szczegółowego raportu o sytuacji we Francji. Zdaniem króla, ze względu na to, że Staël był zięciem Neckera, jego relacje nosiły bowiem znamiona stronniczości. Jeszcze tego samego dnia sekretarz stanu napisał do Silfersparrego, nakazując mu przekazywać królowi jak najwięcej szczegółów odnośnie do tego, co dzieje się we Francji. Wyjaśniał mu przy tej okazji, że Gustaw III nie może niczego zrozumieć $z$ depesz przysyłanych mu przez ambasadora. Przypominając Silfversparremu, że Staël, jako zięć Neckera, zawsze będzie w swoich sądach mniej lub bardziej stronniczy, nakazał mu równocześnie zachowanie pełnej neutralności wobec wydarzeń rozgrywających się na francuskiej scenie politycznej, zobowiązujac go do bezstronnego komentowania zachodzacych tam wypadków. W ten sposób nawiązana została regularna korespondencja Arona Isaca Silfversparrego z dworem sztokholmskim. Sekretarz misji paryskiej rozpoczą sporządzanie, w tajemnicy przed swoim szefem, osobnych raportów przeznaczonych dla króla i sekretarza stanu. Szybko też pozyskał sobie pełne zaufanie obu swoich korespondentów. Zwłaszcza Franc miał jak najlepszą opinię o Silfversparrem. Raporty sekretarza paryskiej ambasady podobały

Historia powszechna 1789-1870, wyd. 4, Warszawa 1977, s. 36-39; A. Soboul, op. cit., s. 90-93; A. Mathiez, Rewolucja..., s. 80-83; L. Villat, op. cit., s. 15-16; J. Baszkiewicz, Historia Francji, wyd. 2, Wrocław 1978, s. 408-409. Por. też idem, S. Meller, Rewolucja francuska 1789-1794. Społeczeństwo obywatelskie, Warszawa 1983, s. 9-16. Szerzej na temat przeciwników zmian zachodzacych we Francji w 1789 r. por. J. Godech ot, La contre-révolution française. Doctrine et action. 1789-1804, Paris 1961, s. 22-55. 
się jednak także królowi. Poglądy Silfversparrego różniły się bowiem zasadniczo od poglądów jego szefa. Będąc zdeklarowanym rojalista o zdecydowanie konserwatywnych zapatrywaniach, nie podzielał on bowiem liberalnych ciagot Staëla von Holsteina i jego nieukrywanej sympatii wobec umiarkowanego nurtu rewolucji francuskiej. Pełne krytycznych uwag pod adresem Francji, Francuzów i własnego szefa, paryskie relacje Silfversparrego w sumie jednak wyraźnie rozczarowuja i nie wytrzymuja w najmniejszym nawet stopniu porównania $z$ pełnymi głębi i przenikliwości politycznej depeszami Erika Magnusa Staëla von Holsteina ${ }^{40}$.

\section{Bibliografia}

\section{Ź RÓDEA ARCHIWALNE}

Riksarkivet w Sztokholmie

Diplomatica: Gallica vol. 470, 471, 471.

Huvudarkivet, Kabinettet/UD, B1B, vol. 125.

\section{ŹRÓDEA DRUKOWANE}

Correspondance diplomatique du baron de Staël-Holstein et de son successeur comme chargé d'affaires le baron Brinkman. Documents inédits sur la révolution (1783-1799) recueillis aux Archives Royales de Suède, ed. L. Leouzon Le Duc, Paris 1881.

Ludwik Filip, Pamiętniki z czasów Wielkiej Rewolucji, oprac. W. Dłuski, wstęp J. Baszkiewicz, Warszawa 1988.

\section{OpRacowania}

Åkeson N., Gustaf III:s förhållande till franska revolutionen, Bd I, Lund 1885.

Anusik Z., Dyplomacja szwedzka wobec kryzysu monarchii we Francji $w$ latach 1787-1792, Łódź 2000.

${ }^{40}$ Por. Notatka Gustawa III na depeszy E.M. Staëla v. Holsteina z 15 X 1789, RA, Gallica vol. 472; U.G. Franc do A.I. Silfversparerego, Sztokholm 17 XI 1789, RA, Huvudarkivet, Kabinettet/UD, B1B, vol. 125; A. Söderhjelm, op. cit., s. 202-210; Z. Anusik, op. cit., s. 249-250. Jednoznacznie pozytywna opinię o sekretarzu legacji paryskiej wyraził Ulric Gustaf Franc w liście pisanym w dniu 31 I 1791 r. do Nilsa Jakobssona. Sprawa dotyczyła mianowania dotychczasowego sekretarza Biura Prezydialnego - Pehra Olofa von Aspa na stanowisko posła szwedzkiego w Stambule. Opuszczone przez niego stanowisko objąć miał wówczas właśnie Silfversparre. Zdaniem Franca miał on być „chłopcem inteligentnym, uczciwym i budzącym zaufanie”. Co zaś wydawało się sekretarzowi stanu jeszcze ważniejsze, „cnotliwym i przywiązanym całym sercem do zasad religii i moralności, które zostały mu wpojone w dzieciństwie”. Por. A. Söderhjelm, op. cit., s. 203. 
Barton H.A., Gustav III of Sweden and the Enlightement, „Eighteenth Century Studies. An Interdisciplinary Journal”, vol. VI, No. 1, Berkeley (Univeristy of California) 1972-1973.

Baszkiewicz J., Historia Francji, wyd. 2, Wrocław 1978.

Baszkiewicz J., Ludwik XVI, Wrocław 1983.

Baszkiewicz J., Meller S., Rewolucja francuska 1789-1794. Społeczeństwo obywatelskie, Warszawa 1983.

Bielecki R., Bastylia 1789, Warszawa 1991.

Den introducerade svenska adelns ättartavlor, utg. G. Elgenstierna, Bd VII, Stockholm 1932.

Egret J., La pré-révolution française (1787-1788), Paris 1962.

Egret J., La révolution des notables: Mounier et les monarchiens. 1789, Paris 1950.

Egret J., Necker, ministre de Louis XVI. 1776-1790, Paris 1978.

Geffroy A., Gustave III et la cour de France. Suivi d'une étude critique sur Marie-Antoinette et Louis XVI apocryphes, t. I-II, Paris 1867.

Godechot J., La contre-révolution française. Doctrine et action. 1789-1804, Paris 1961.

Godechot J., La prise de Bastille. 14 Juillet 1789, Paris 1965.

Kumljen K., Staël von Holstein Erik Magnus, [w:] Svenska Män och Kvinnor. Biografisk Uppslagsbok, Bd VII, Stockholm 1954, s. 172.

Lefebvre G., La grande peur de 1789, Paris 1932.

Lefebvre G., The Great Fear of 1789: Rural panic in revolutionary France, introd. G. Rudé, New York 1989.

Leouzon Le Duc L., Introduction [w:] Correspondance diplomatique de baron de Staël-Holstein ambassadeur de Suède en France et de son successeur comme chargé d'affaires le baron Brinkman. Documents inédits sur la révolution (1783-1799) recouillis aux Archives Royales se Suède, publ. L. Leouzon Le Duc, Paris 1881.

Mathiez A., La révolution française, t. I (La chute de la royauté 1787-1792), Paris 1928.

Mathiez A., Rewolucja francuska, Warszawa 1956.

Mignet M., Historya rewolucyi francuskiej od roku 1789 do 1814, Warszawa 1890.

Repertorium der diplomatischen Vertreter aller Länder, Bd III (1764-1815), hrsg. O.F. Winter, Graz-Köln 1965.

Soboul A., Rewolucja francuska, Warszawa 1951.

Söderhjelm A., Sverige och den franska revolutionen. Bidrag till kännedom om Sveriges och Frankrikes inbördes förhållande i slutet av 1700-talet, Bd I (Gustav III:s tid), Stockholm 1920.

Sorel A., Mme de Staël, Paris 1890.

Villat L., La révolution et l'Empire (1789-1815), t. I (Les Assemblées révolutionnaires 1789-1799), Paris 1947.

Wickman J., Madame de Staël och Sverige. Bidrag till Madame de Staëls biografi. Huvudsakligen efter hittills otryckta originalihandskrifter, Lund 1911.

Żywczyński M., Historia powszechna 1789-1870, wyd. 4, Warszawa 1977. 


\title{
Events in France during first months of the Revolution (May-October of 1789) in the light of reports of the Swedish Ambassador to Paris (Versailles) Erik Magnus Staël von Holstein
}

\begin{abstract}
E rik Magnus Staël von Holstein (*1749) became an Ambassador of Sweden to C Paris (Versailles) in November of 1783. In January of 1786 he married Anne Louise Germaine Necker, the daughter of a Swiss banker and one of the richest men in France - Jacques. After a wedding with the daughter of Jacques Necker the position of the Swedish Ambassador in France was quite unique. He was well seen both in Versailles, where he enjoyed the sympathy on the part of Louis XVI, Marie Antoinette, princes of the blood, nobility and courtiers, and in Paris, where through his father-in-law he had established contacts with the environment of financiers, merchants and noblesse de robe. Staël also proved to be an excellent observer of the French political scene. In terms of political beliefs he was a supporter of the constitutional monarchy. For this reason, he condemned despotism of Louis XVI as well as of his own monarch. He was generally regarded as an aristocratic liberal. After having taken an office of the representative of the interests of the King of Sweden at the court of Versailles, Erik Magnus Staël von Holstein was sending to Stockholm very interesting diplomatic reports which recorded all current events taking place in France. At a time when the absolute monarchy of Louis XVI began to waver in its foundations, as an aristocratic liberal and son-in-law of Necker, he sympathised with the opposition of nobles and parliaments against actions of the Royal Government. On the basis of Staël von Holstein's very detailed reports we have the possibility of keeping trace of the „revolt of the privileged”. During first months of the Revolution he was sending to Stockholm full of depth and political insight reports with a detailed description of events taking place in France. Presented by Staël image of the French political scene does not differ in principle from the way modern historians are writing about it. It is also impossible to find fault in his reports. The Ambassador was usually fairly informed about events taking place in France and even if he was wrong in some small details, he was able to penetrate an essence and atmosphere of change of which he was an eyewitness.
\end{abstract}

Keywords: Sweden-France in $18^{\text {th }}$ century, Swedish diplomatic service, French revolution 1789-1799, Erik Magnus Staël von Holstein. 